\title{
A REVIEW OF THE VARIETIES OF HUMAN HAEMOGLOBIN IN HEALTH AND DISEASE
}

BY

\author{
J. C. WHITE AND G. H. BEAVEN \\ From the Department of Haematology (Pathology), Postgraduate Medical School of London, and the \\ M.R.C. Spectrographic Unit, The London Hospital
}

(RECEIVED FOR PUBLICATION JUNE 15, 1954)

\begin{tabular}{|c|c|c|c|}
\hline & Page & & $P c$ \\
\hline JTRODUCTION & 175 & Spectrophotometry of $\mathrm{Hb}-\mathrm{F}$ & 18 \\
\hline $\begin{array}{c}\text { THE OXYGEN-CARRYING FUNCTION OF HAEMO- } \\
\text { GLOBIN } \ldots . .\end{array}$ & & $\begin{array}{l}\text { The Oxygen Dissociation Curve for Foetal } \\
\text { Blood }\end{array}$ & \\
\hline 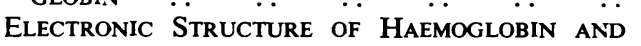 & $1 / 6$ & $\begin{array}{l}\text { Blood } \\
\text { Oxidation of Foetal Haemoglobin to Methae- }\end{array}$ & \\
\hline ITs Derivatives ... & 178 & moglobin $\quad . . \quad$. & \\
\hline Bond Type in Metal Complexes & 179 & Clinical Significance of Foetal Haemoglobin & \\
\hline The Haem-Globin Bond $\quad .$. & 179 & SICKLE-CELl DiseaSe aND SickLe-Cell HaEMo- & \\
\hline General Properties of Haemoglobin as a & & GLOBIN (HAEMOGLOBIN S) & \\
\hline $\begin{array}{l}\text { GLOBULAR ProteIN } \ldots \\
\text { The Properties of Haemoglobin in } \ddot{\text { Solution }}\end{array}$ & $\begin{array}{l}181 \\
181\end{array}$ & Electrophoretic Properties of & \\
\hline Amino-acid Composition of Globin & 182 & $\begin{array}{l}\text { Haemoglobin } \\
\text { Paper Electrophoresis }\end{array}$ & \\
\hline Immunological Properties of Haemoglobin & 183 & The Solubility of Sickle-cell Haemoglobin ... & \\
\hline The Solubility of Haemoglobin & 183 & Gel-formation by Reduced $\mathrm{Hb}-\mathrm{S}$ & \\
\hline $\begin{array}{l}\text { The Shape of the Haemoglobin Molecule .. } \\
\text { Crystallography of Human Haemoglobin ... }\end{array}$ & $\begin{array}{l}184 \\
184\end{array}$ & $\begin{array}{c}\text { Other Characteristics of Sickle-cell Haemo- } \\
\text { globin }\end{array}$ & \\
\hline Foetal HaEmoglobin & 185 & Foetal Haemoglobin in Sickle-cell Anaemia & \\
\hline Crystallographic Differences & 185 & The Genetics of Sickle-cell Anaemia .. & \\
\hline Solubility Differences $\quad \ldots \quad \ldots$ & 185 & NS IN $\mathrm{F}$ & \\
\hline $\begin{array}{l}\text { Differences in Amino-acid Composition } . . \\
\text { The Immunological Specificity of Foetal }\end{array}$ & 185 & IA INTERACTION & \\
\hline Human Haemoglobin.. & 185 & HaEMOGLOBIN C & \\
\hline Alkali-denaturation of Adult and Foetal & & HAEMOGLOBIN D & \\
\hline Monomolecular Films of Adult and Foetal & 186 & HAEMOGLOBIN E $\quad$. & \\
\hline Haemoglobins & 18 & CONCLUSION & \\
\hline Electrophoresis of Foetal Haemoglobin & 188 & REFERENCES .. & \\
\hline
\end{tabular}

Haemoglobin is a member of the important class of conjugated proteins, the haem-proteins. The members of this class enter into a wide diversity of reactions in the living organism concerned with oxidation-reduction and oxygen transporting mechanisms. All possess the common structural feature of iron-porphyrin prosthetic groups united with protein; variation in the nature of the haem occurs (cytochrome), but protohaem (ferroor ferri-protoporphyrin IX) is common (haemoglobin, catalase, horse-radish peroxidase). The nature of the protein and of the linkages to the prosthetic group are of great importance in determining the type of activity of these proteins. In all higher animals, haemoglobin is concerned principally with oxygen-transport, this property being determined largely by the coordination of ferrous iron in the protoporphyrin molecule, and the nature of the linkage of the four haem groups to the surface of the globin.

Haemoglobin is by no means confined to the erythrocytes of higher animals, and is of extremely widespread occurrence in nature (Anson and Mirsky, 1925). For instance, it occurs in the rootnodules of leguminous plants containing rhizobium, and plays a part in nitrogen-fixation (Virtanen and Laine, 1946; Keilin and Smith, 1947). Haemoglobin is also found dissolved in the blood of the crustacean genus Daphnia, particularly under conditions of low oxygen tension, and in the partho- 
genetic eggs (Fox, Gilchrist, and Phear, 1951). Haemoglobin also occurs in yeasts (Keilin, 1953), the moulds Neurospora crassa and Penicillium notatum (Keilin and Tissières, 1953), and the protozoa Paramecium caudatum and Tetrahymena pyriformis (Keilin and Ryley, 1953). Keilin (1953) points out that non-circulating haemoglobins occur in very variable amounts in cells, and are not necessarily actively involved in the respiration, but may arise in the course of active synthesis of haemo-proteins.

It is not surprising that the globin moiety varies in different haemoglobins, the iso-electric point and amino-acid composition varying from species to species (Lemberg and Legge, 1949), and the molecular weight being very high in haemoglobins from some invertebrates (Prosser, 1950). The haem does not vary in structure. Within single species variants of haemoglobin may occur which differ slightly in structure and properties. Until recently the best characterized intra-species variants were the adult and foetal forms of haemoglobin found in many animals and in man. However, the discovery that sickle-cell haemoglobin differs from normal adult human haemoglobin, that it is formed under genetic control, and that its presence is related to the clinical manifestations of sickle-cell disease has stimulated work in this field. Several genetically determined variants of adult human haemoglobin are now recognized, and Pauling and his colleagues have advanced the concept of a "molecular disease" in conditions such as sicklecell anaemia, where a variation in a normal protein on the molecular level leads to functional disturbance (Pauling, Itano, Singer, and Wells, 1949).

This review will be concerned chiefly with the variants of human haemoglobin that are known to occur in disease. Besides normal adult and foetal haemoglobin and sickle-cell haemoglobin three other variants have been characterized (Table I).

TABLE I

NOMENCLATURE OF HUMAN HAEMOGLOBIN VARIANTS

\begin{tabular}{|c|c|c|c|}
\hline & \multicolumn{3}{|c|}{ Symbol } \\
\hline & $\begin{array}{l}\text { (Blood, } \\
8,386)\end{array}$ & $\begin{array}{c}\text { (Itano, } \\
1953 \mathrm{a}, \mathrm{b})\end{array}$ & $\begin{array}{c}\text { (Singer and } \\
\text { Chernoff, } \\
\text { 1952) }\end{array}$ \\
\hline 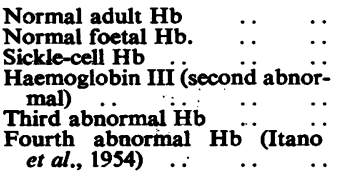 & $\begin{array}{l}\mathbf{A} \\
\mathbf{F} \\
\mathbf{S} \\
\mathbf{D} \\
\mathbf{E}\end{array}$ & $\begin{array}{l}\mathbf{a} \\
\mathbf{f} \\
\mathbf{b} \\
\mathbf{c} \\
\mathbf{d}\end{array}$ & $\begin{array}{l}\mathbf{N} \\
\mathbf{F}\end{array}$ \\
\hline
\end{tabular}

It is possible that further forms will be discovered. The recognition of these haemoglobins depends on the application of various physico-chemical methods of protein chemistry. The significance of these haemoglobins in relation to clinical syndromes and the nature of their departure from normal haemoglobin structure must therefore be assessed against the general background of haemproteins and the physical chemistry of proteins. Techniques, such as electrophoresis, solubility measurement, and spectrophotometry, play a recognized part in this work but future developments may involve many other methods of protein investigation.

Quite apart from the structural variants in haemoglobin that depend upon slight differences in the protein moiety, and which are efficient oxygen-carrying pigments as far as is known, several modifications of haemoglobin may occur in which the haem-group is involved and the oxygencapacity of the blood reduced. These may result entirely from the effects of toxic chemicals (sulphaemoglobinaemia and most instances of Heinz-body anaemia) or from either toxic or genetic factors (the methaemoglobinaemias).

A number of monographs and reviews deal with various aspects of haemoglobin. Wide general treatment is given in the monograph "Hematin Compounds and Bile Pigments" (Lemberg and Legge, 1949) and the review "Chromoproteins" (Drabkin, 1951). Physico-chemical aspects are dealt with in the Barcroft memorial volume, "Haemoglobin" (1949), and in a review by Wyman (1948). The physico-chemical basis for the recognition of abnormal human haemoglobins has been dealt with by one of us (White, 1954) and to avoid duplication some aspects will be condensed as far as possible in the present work. Haurowitz and Hardin (1954) have recently discussed the protein chemistry of haemoglobin and the haemo-proteins. An excellent general review of the abnormal haemoglobins encountered in hereditary anaemias, especially Hb-S, has been given by Harris (1953), who discusses the genetic aspects of the subject in some detail (see also Gajdos, 1953).

\section{THE OXYGEN-CARRYING FUNCTION OF HAEMOGLOBIN}

The outstanding function of intracorpuscular haemoglobin is the transport of oxygen from the lungs to the tissues. In addition, it plays an im. portant part in the transport of carbon dioxide from the tissues to the lungs, and in maintaining the hydrogen ion concentration of the blood.

The ability of haemoglobin to transport oxygen depends upon the ability of the weak acid, haemoglobin, to form a loose molecular compound with 
oxygen; the resulting oxyhaemoglobin is a slightly stronger acid at physiological $p \mathbf{H}$ but readily dissociates on reducing the partial pressure of oxygen: $\mathrm{Hb}+\mathrm{O}_{2} \rightleftharpoons \mathrm{HbO}_{2}$. Under favourable conditions, as within the intact erythrocytes, the reversible oxygenation is effected without any significant oxidation to methaemoglobin. If preparations of haemoglobin are exposed to varying partial pressures of oxygen, which are then plotted against the resulting degrees of saturation of haemoglobin with the oxygen, oxygen dissociation curves are obtained. These are based upon the form of a rectangular hyperbola, but a variety of conditions result in the curve assuming a more sigmoid form. This is notably so with intact red cells (Hill, 1935; McCarthy, 1943), and is advantageous under physiological conditions in that the oxygen is more readily given up to tissues at low oxygen tension.

The specific oxygen capacity is the relation of the oxygen to the iron in haemoglobin (Barcroft, 1928). The iron content of haemoglobin was determined by Hüfner (1894) as $0.334 \%$, and the oxygen uptake as $1.34 \mathrm{ml}$. per g. of haemoglobin; this is equivalent to the binding of one molecule of oxygen per atom of iron. With crystalline haemoglobin, Bernhart and Skeggs (1943) found that the oxygen capacity was slightly less than that expected from the iron-analysis, though the difference is much smaller than that based on Haldane's (1900) original standard of $13.8 \mathrm{~g}$. of haemoglobin per 100 $\mathrm{ml}$. of normal blood, with an oxygen capacity of $18.5 \mathrm{ml}$. of oxygen $/ 100 \mathrm{ml}$. King, Gilchrist, Wootton, Donaldson, Sisson, Macfarlane, Jope, O'Brien, Peterson, and Strangeways (1947) find the B.S.I. standard tube ( $100 \%$ Haldane) is equivalent to $14.8 \mathrm{~g}$. haemoglobin $/ 100 \mathrm{ml}$. of blood when measured by iron analysis, or $14.4 \mathrm{~g}$. when measured by oxygen capacity. The slight difference may be attributable to small amounts of nonfunctional pigments derived from haemoglobin. The difference is of course proportionately increased when pathological concentrations of methaemoglobin, sulphaemoglobin etc., are present in the blood.

Attempts to analyse the form of the oxygen dissociation curve of haemoglobin were not entirely successful until Adair $(1924,1925 a)$ determined by osmotic pressure measurements the molecular weight of mammalian haemoglobin to be 68,000 ; this requires four atoms of iron per molecule. Adair (1925b) then considered the process of oxygenation to proceed by step-wise union with the four iron atoms; Pauling (1935) extended this treatment by considering six possible intermediates, with the four haem groups arranged at the corners of a square, and interaction of the haems occurring via the oxygen molecules.

The form of the oxygen dissociation curve of haemoglobin solution and of whole blood is influenced by a number of factors, such as the electrocytes present, temperature, partial pressure of carbon dioxide present (Bock, Field, and Adair, 1924), and hydrogen ion concentration. Increase in the last three factors all produce a more sigmoid curve. The concentration of haemoglobin is important, dilute solutions giving more hyperbolic curves whilst concentrated solutions and intact corpuscles give sigmoid curves. These factors are discussed at length by Barcroft $(1928,1946)$.

Valtis and Kennedy (1954) have recently brought out a point of considerable clinical interest in connexion with transfusion of stored red cells. They found that the oxygen-dissociation curve of cells which had been stored in acid-citrate-dextrose medium at $4^{\circ} \mathrm{C}$. was shifted to the left, this effect being progressive with prolonged storage. Transfusion of blood stored for seven days or more resulted in a similar change in the oxygen dissociation curve of the recipient's blood, the effect lasting for several hours, during which time proportionately less oxygen could be released from the blood to the tissues. The change in the oxygen dissociation curve was considered due to changes in the physical, chemical, and electrolytic relations between stored cells and plasma and not to chemical changes in the haemoglobin (Valtis and Kennedy, 1953).

The form of the oxygen dissociation curve is fundamentally influenced by the type of haemoglobin. Thus, wide differences occur throughout the animal kingdom, particularly with regard to the effect of temperature (see Barcroft, 1928). Foetal and adult forms differ, and this will be discussed subsequently. We are not aware of any detailed studies on the oxygen dissociation curve in human blood where the variants, sickle-cell, C, or D haemoglobins are present. Such studies might be of considerable interest, particularly where foetal haemoglobin is also a concomitant.

A good deal is known about the form of the oxygen dissociation curve of haemoglobin in the presence of chemical derivatives such as carboxyhaemoglobin and methaemoglobin. The shift to the left which occurs must contribute to the degree of tissue anoxia, which, in carbon monoxide poisoning particularly, is out of proportion to the amount of abnormal pigment present.

Haldane and Smith (1897) observed that miners could work with a simple anaemia of less than $50 \% \mathrm{Hb}$, but reduction of the oxygen capacity to 
the equivalent level by carbon monoxide poisoning often produced collapse. Douglas, Haldane, and Haldane (1912) observed that the dissociation curves for both oxygen and carbon monoxide have the same sigmoid form though the affinity for $\mathrm{CO}$ is far greater, but that the curve for oxyhaemoglobin becomes less sigmoid in the presence of carboxyhaemoglobin. Roughton and Darling (1944) showed that the curve moves progressively to the left when the percentage oxygen saturation is plotted against partial pressure of oxygen in the presence of 20,40 , and $60 \%$ carboxyhaemoglobin, and that this result would be expected from Pauling's (1935) equation for haem-interaction only if the interaction constants were the same for combination of haemoglobin with oxygen and with CO.

Similar observations have been made by Darling and Roughton (1942) in the case of mixtures of methaemoglobin and ordinary haemoglobin, the shift to the left increasing with increasing percentage of methaemoglobin, and being qualitatively the same as in the presence of carboxyhaemoglobin, though quantitatively less. This effect on the oxygen dissociation curve has been confirmed by Gibson and Harrison (1947) in the familial idiopathic methaemoglobinaemia (see also Baikie and Valtis, 1954). The tendency to tissue anoxia in the case of methaemoglobinaemias is important clinically, and may also obtain in sulphaemoglobinaemias, where cyanosis may be very marked in the presence of only 10 to $15 \%$ of the abnormal pigment.

\section{ELECTRONIC STRUCTURE OF HAEMOGLOBIN AND ITS DERIVATIVES}

The discussion of the nature of the binding of iron to porphyrin in the haem pigments, the combination of haem with globin to form the conjugated protein haemoglobin, and the manner in which the latter combines reversibly with oxygen and irreversibly with various other compounds to give products of physiological or clinical importance requires a brief note on certain modern valency concepts (Pauling, 1940 ; Palmer, 1944).

In the general process of bond formation between $A$ and $B$ (which may each be neutral atoms or molecules, ions) the following extreme or pure bond types may be concerned :

$$
\mathrm{A}^{+} \ldots \mathrm{B}^{-} \quad \mathrm{A}: \mathbf{B} \quad \mathbf{A}: \mathbf{B}
$$

(a)

(b)

(c)

In the ionic bond (a) the bonding force is essentially the Coulomb attraction between charge centres of opposite sign. In the crystalline state ionic bonds result in extended lattices in which the individual ions are arranged in a three-dimensional pattern of minimum potential energy. In appropriate solvents ionic compounds dissociate to form free ions which are stabilized by hydration with solvent molecules and the solute molecule does not exist as such.

In the covalent bond (b) each partner of the bonding process contributes one electron to the electron pair which constitutes the bond. In this bond the electron spins (see below) are paired and the bonded state is energetically more stable (by an amount expressed by the bond energy) than the non-bonded state. The extent to which the electron pair is shared between $A$ and $B$ depends on the relative electronegativities of the bonded atoms etc. When these are dissimilar the sharing is in general unequal and there is some charge distribution across the bond.

In the coordinate bond (c) both electrons required to form the two-electron bond are contributed by one partner $A$ of the bond. The bonding process is therefore accompanied by charge transfer from $A$ to $\mathrm{B}$, giving rise to a marked dipole in the sense shown. The special conditions required for coordinate bond formation are a pair of unshared electrons (lone pair) on the donor and a vacant electron orbital on the acceptor.

In practice (excluding special cases as pure covalently bonded diatomic molecules formed from identical atoms) bonds are not pure ionic or pure covalent but have to be regarded as essentially ionic or essentially covalent. Similarly in the coordinate bond, which plays an important role in complex formation, the charge transfer is not confined to the bond, but may be re-distributed through the whole molecule (cf. hexahydrated $\mathrm{Fe}^{++}$ion, below). All three types of bonding are involved in the chemistry of haemoglobin.

The resonance concept of molecular structure is of importance in the structure of the porphyrins and of the haem-proteins. It is sufficient to state that if more than one arrangement of bonds can be written which satisfies the required spatial arrangement of the atoms in a molecule, then the various structures which can be so written may interact energetically to form a hybrid structure which is more stable than any of the individual structures. The gain in stability so achieved is the resonance energy of the molecule, and individual structures which are themselves energetically improbable may by resonance make significant contributions to the character of the resonance hybrid. Thus ionic structures may contribute to a predomin- 
antly covalent structure and vice versa. The stabilization arising from resonance provides an explanation for the complexity of bond type, e.g. the partial ionic character of an otherwise pure covalent bond, or the partial double-bond character of bonds which would be of pure single-bond character in the absence of resonance.

An important experimental criterion of bond type much used in the study of haemoglobin is the magnetic character of the bonding entities and of the resulting compound. In the covalent bond the intrinsic magnetic moments of the bonding electrons (which largely arise from their spins) are paired in opposition, so that there is no resulting magnetic moment. In certain metallic atoms, e.g. Fe, some of the valency electrons exist singly in orbitals capable of holding two paired electrons. The spin of the electrons in these singly occupied orbitals is thus unpaired and gives rise to paramagnetism of the metal atom, which can be estimated theoretically and measured.

The electronic structures of haemoglobin and its derivatives have been discussed in terms of the concepts outlined above in an attempt to provide fundamental explanations for their properties. The structures which have been proposed are largely due to Pauling (1949, cf. Lemberg and Legge, 1949) and are based on the principle of approximate electrical neutrality which states " that in a stable molecule, the electronic structure is such as to associate with each atom the number of electrons that makes the residual electric charge of the atom zero, or, at the most a small fraction of an electronic charge". A simple example is the hexahydrated ferrous ion $\left(\mathrm{Fe}\left(\mathrm{OH}_{2}\right)_{6}\right)^{++}$in which each of the six $\mathrm{Fe}-\mathrm{H}_{2} \mathrm{O}$ bonds has about one-third covalent, two-thirds ionic character, as required by the relative electronegativities of $\mathrm{Fe}$ and $\mathrm{O}$. The overall effect of the coordination bonding process is therefore to transfer $6 \times \frac{1}{3}=2$ units of negative charge to the iron atom, just sufficient to balance the original charge of +2 on $\mathrm{Fe}^{++}$; in the complex the net charge of +2 is thus distributable over the $12 \mathrm{H}$ atoms of the complex.

\section{Bond Type in Metal Complexes}

In haem (ferroporphyrin) magnetic data indicate four unpaired electrons, corresponding to the four unpaired electrons in the $\mathrm{Fe}^{++3 d}$ orbitals (Lemberg and Legge, 1949). The bonding is therefore essentially ionic, the two pyrrole $\mathrm{H}$ atoms dissociating as protons and being replaced by $\mathrm{Fe}^{++}$; the negative charge left on the porphyrin is equally distributed among the four central $\mathrm{N}$ atoms by resonance and the net charge of the haem is therefore zero (apart from possible ionization of side chain carboxyl groups (I).<smiles>C1CNC2(N1)NCO2</smiles>

(I)<smiles>[X]C1NCCN1</smiles>

(II)
Haemin and haematin containing ferric iron, $\mathrm{Fe}^{+++}$, resemble haem in having essentially ionic bonds, but the complex has a net charge of +1 (II) and is therefore associated with an anion, i.e., $\mathrm{ce}^{-}$. The exact bond types and the electronic orbitals employed in these complexes is still the subject of discussion.

The elestronic configuration of the metal permits the attachment of two more coordinating groups, in which case the stereochemistry of the bonds changes from planar to octahedral. If the additional groups are electrically neutral the net charge of the complex is unaltered (e.g. III) and if not (e.g. $\mathrm{OH}^{-}$) then it may neutralize the net charge.

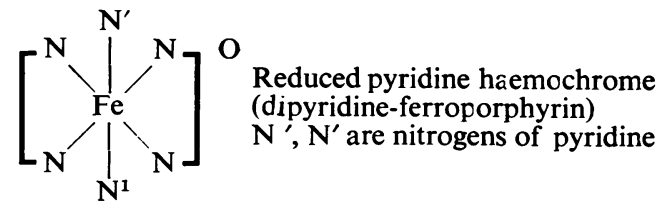

(IV)
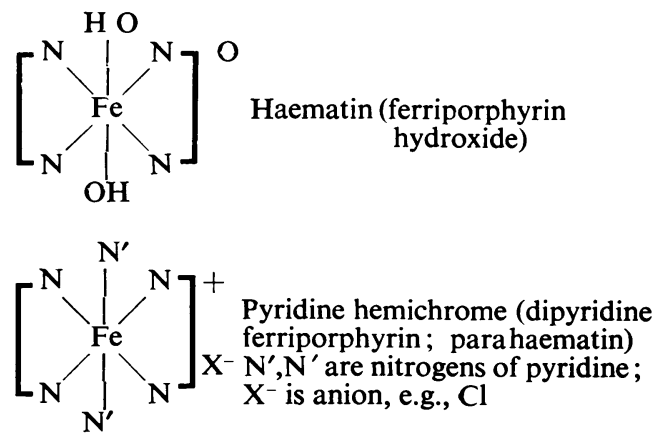

\section{The Haem-Globin Bond}

The haem-globin bond can be split by acid acetone to give free globin and the appropriate haem and globin, but not by proteolytic enzymes (cf. Haurowitz and Hardin, 1954). The exact nature of the bond is still obscure, but at least one $\mathrm{N}$ atom of the globin, contained in a histidine ring, is coordinated to the iron atom. Haurowitz (1949) has presented evidence that the sixth coordination position is occupied by a water molecule; if so, native ferrohaemoglobin is an aquo-complex (VI) 
while in oxyferrohaemoglobin the attachment of oxygen requires the sixth position (VII)

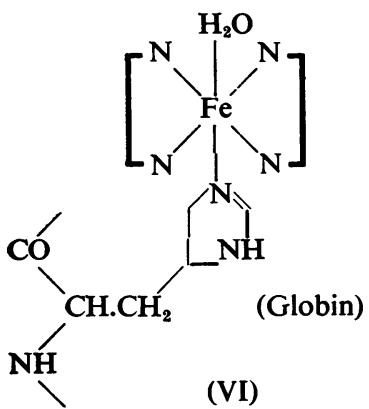<smiles>O=C1N2CCN(CC2)C12CC(C(Cl)Cl)NC=N2</smiles>

(VII)

Other workers have suggested that two such " haemaffine" groups of the globin are bonded to the iron in ferrohaemoglobin and that one is displaced in oxygen combination. The change in acidity which accompanies the latter, and which most probably involves the NH of a histidine ring, is an important part of the detailed evidence for histidine residues as the bonding agency (cf. Lemberg and Legge, 1949).

In ferrohaemoglobin the paramagnetism indicates ionic bonding, as in the simple haem complexes. Reversible combination with oxygen gives oxyferrohaemoglobin which is diamagnetic, indicating a profound change in electronic structure to the essentially covalent type. The bonding of the oxygen to the metal is in accordance with the principle of approximate electrical neutrality, in which both the metal and the oxygen each contribute two electrons to form what is essentially a double bond, subject, however, to certain resonance processes (VIII, IX).<smiles>CN1CCN(C(=O)N2CCNC2=O)C1</smiles>

(VIII)

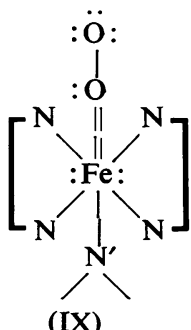

(IX)
$\mathbf{N}^{1}$ denotes $\mathbf{N}$ of histidine residue of globin.

(The six electrons around the $\mathrm{Fe}$ atom are those which occupy the five $3 \mathrm{~d}$ orbitals in $\mathrm{Fe}^{++}$and are responsible for its paramagnetism.)

Similar structures can be written for the compounds of ferrohaemoglobin with carbon monoxide, cyanide ion, and the alkyl isocyanides, viz. (X, XI, XII).

Other derivatives of ferrohaemoglobin are discussed by Lemberg and Legge (1949). The nitroso- benzene compound may be of pharmacological importance (Keilin and Hartree, 1943).<smiles>CN(C)C12CCN(CC1)C(=O)NC2</smiles>

(X)<smiles>CN1CCNC1(C#N)NCCN</smiles>

(XI)

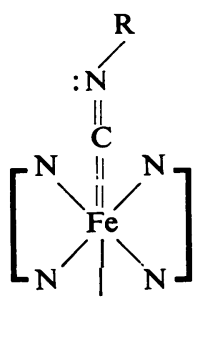

(XII)
The ferrihaemoglobin (methaemoglobin) compounds contain iron in the ferric state $\left(\mathrm{Fe}^{+++}\right)$, and the resulting net charge is +1 . Paramagnetic methaemoglobin with a charge of +1 may be written as (XIII); in alkaline solution the sixth position is occupied by $\mathrm{OH}^{-}$giving methaemoglobin hydroxide (XIV, alkaline methaemoglobin) with a

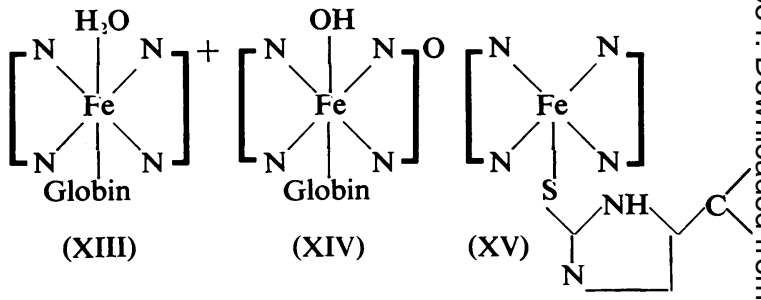

fall in magnetic susceptibility. Methaemoglobin derivatives involving combination with fluoride, cyanide (cyanmethaemoglobin), azide, nitric oxide, hydrosulphide, etc., have been described.

The exact nature of the clinically important pigment sulphaemoglobin characterized by an absorption band at about $620 \mathrm{~m} \mu$ is still obscure (Lemberg and Legge, 1949) and various structures have been proposed, e.g. (XV) involving a covalent S-iminazole band.

Methaemalbumin (ferrihaemalbumin) is an abnormal component of blood plasma in certain diseases associated with excessive haemolysis in which the linkage is probably from the carboxylic acid side-chain groups of the haem to basic groups in the protein, which is serum albumin. The literature on this compound is discussed by Lemberg and Legge (1949) ; Rosenfeld and Sugenor (1950) have studied the stoichiometry of its formation from serum albumin and ferriprotoporphyrin IX (haemin chloride) and give spectrophotometric data showing the striking $403 \mathrm{~m} \mu$ Soret band of methaemalbumin which is sharper and nearly $70 \%$ more intense than that of the parent haemin at the same molar concentration. 


\section{GENERAL PROPERTIES OF HAEMOGLOBIN AS A GLOBULAR PROTEIN}

The globin moiety is readily split from haemoglobin with mineral acids in organic solvents, such as hydrochloric acid-acetone (Schulz, 1898). The white precipitate of denatured globin obtained at room temperature is water soluble, but precipitated by ammonia. This globin has often been classified with the histones. However, the amino-acid composition is quite different, and the highly individual character of globin has emerged in work using undenatured globin split from haemoglobin at low temperatures in acid-acetone (Hill and Holden, 1926). Anson and Mirsky (1930) showed that the globin and haematin split at $-15^{\circ} \mathrm{C}$ were capable of recombination, and Jope, Jope, and O'Brien (1949) succeeded in splitting human haemoglobin and recombining it to yield crystalline methaemoglobin, from which crystalline derivatives such as reduced oxy- and carboxyhaemoglobin were prepared, all of which closely resembled their normal counterparts as judged by searching spectrophotometric tests.

The ferrous iron atoms of haemoglobin form a Werner coordination complex with the porphyrin ring nitrogens and with the protein (Haurowitz and Waelsch, 1929), and further evidence for this has been reviewed by Pauling (1949), Lemberg and Legge (1949), and by Wyman (1949). The mutual interaction of haem, protein, and oxygen is illustrated by the decreased affinity of haemoglobin for oxygen in the presence of carbon dioxide (Bohr, Hasselbalch, and Krogh (1904) and the converse mechanism (Christiansen, Douglas and Haldane, 1914) due to the increased acidity of oxyhaemoglobin (Roughton, 1944). Conant (1933) considered that the haems might be bound to two " haemaffine" groups, probably imidazole groups, and the more recent electronic treatment follows the same lines, though a molecule of water may occupy one coordination position in reduced haemoglobin according to Haurowitz (1949).

The relative ease of splitting of the bonds between haem and globin forms the basis of some methods for identifying haemoglobin variants, and will be discussed below.

\section{The Properties of Haemoglobin in Solution}

The Molecular Weight.-Unlike invertebrate haemoglobins, which vary widely in molecular size, vertebrate haemoglobins all have a molecular weight of 68,000 and the molecule contains four haem groups. Adair (1924, 1925 a and b) established this value by osmotic pressure measurements on salt-free, $4 \%$ solutions at $-0.6^{\circ} \mathrm{C}$, and this was confirmed by subsequent measurements of the diffusion constant (Northrop and Anson, 1929), and of the sedimentation constant in the ultra-centrifuge (Svedberg and Nichols, 1927).

Burk and Greenberg (1930) found that in concentrated urea solution $(6.66 \mathrm{M})$ between $p \mathrm{H} 7.3$ and 9 the molecular weight of haemoglobin is halved, as judged by the osmotic pressure. Wyman (1949) found that two haem groups are associated with each half-molecule, and the x-ray diffraction data of Perutz (1949) indicates a diad axis of synmetry passing through the centre of the intact haemoglobin molecule. In the special case of one crystalline form of sickle-cell haemoglobin, the evidence from $x$-ray diffraction indicates that the molecules in the large unit cell are twice the normal molecular weight.

The iso-electric points of mammalian haemoglobins are usually just on the acid side of 7 , whereas for invertebrate haemoglobins the points are usually lower. Slight variation in the iso-electric points of the various human haemoglobins provides the basis for their recognition by electrophoretic analysis (vide infra).

Electrophoresis of Haemoglobin.-The application of "free" or gravitationally stabilized moving-boundary electrophoresis to the analytical and preparative separation of mixtures of proteins in solution is due largely to Tiselius (1937, 1940), who introduced the experimental features which are responsible for the great practical value of the technique. It has been frequently described and critical reviews of its application to the study of plasma proteins (Edsall, 1947), and for preparative separations generally (Svensson, 1948) give adequate literature references (see also Longsworth, 1942). The electric mobility of a globular protein over a wide range of $p \mathrm{H}$ values is one of the most important methods of characterizing a protein quantitatively and demonstrating its purity.

The first systematic application of boundary electrophoresis to haemoglobins is attributed to Stern, Reiner, and Silber (1945), who cite some earlier work. Stern et al. obtained wellresolved single peaks for the haemoglobins (run as $\mathrm{HbO}_{2}$ ) from haemolysates of man, dog, and chicken bloods, and minor peaks due to colourless proteins, one of which appeared to be due to membrane or stromal protein. Chicken haemoglobin gave a complex peak, but this possible indication of heterogeneity was not further studied.

The electrophoretic analysis of bloods containing $\mathrm{Hb}-\mathrm{F}, \mathrm{Hb}-\mathrm{S}$, and other abnormal haemoglobins is discussed below. 
In free electrophoresis the movement and separation of boundaries between overlapping components of different mobility is observed, usually optically. In zone electrophoresis the components migrate as separate zones and are stabilized against convection by the supporting medium. For low-molecular substances this may be a gel but for work with proteins filter-paper has received most attention. Because of the simplicity of the equipment, the possibility of essentially complete separation of the components of complex mixtures and the small samples required, zone electrophoresis on filterpaper has been used by a large number of workers for the study of proteins, notably the blood serum proteins. General reviews of the subject have been published by Lederer (1951), Tiselius and Flodin (1953), Fisher (1953b), and Martin and Franglen (1954). As pointed out by Tiselius and Flodin (1953), the many types of apparatus that have been described for zone electrophoresis on filter paper all derive essentially from those of Durrum (1950) with a freely-hanging non-horizontal strip; Wieland (1948) with freely-hanging horizontal paper ; and Cremer and Tiselius (1950) with supported horizontal paper. Martin and Franglen (1954) have most recently summarized the growing literature on the subject with respect to apparatus and applications. The chief disadvantage of zone electrophoresis, as compared with the boundary method, is its present inability to provide absolute mobility data and iso-electric point estimates because of complicating factors introduced by the supporting medium. These limitations have been discussed by Kunkel and Tiselius (1951), who propose some correction procedures. McDonald, Urbin, and Williamson (1951) have also studied the determination of isoelectric points.

It should perhaps be pointed out that the quantitative evaluation of protein zone-electrophoresis patterns on filter-paper is not always easy and has been the subject of much debate (cf. Martin and Franglen, 1954). Quantitative comparisons between free boundary and zone electrophoretic analysis have been made by several workers (Kunkel and Tiselius, 1951; Flynn and de Mayo, 1951 ; Ott, Huber, and Körver, 1952) and a considerable measure of agreement is generally observed in favourable cases.

Denaturation of Haemoglobin.-A large proportion of the extensive literature on the denaturation of proteins is concerned with haemoglobin, because its characteristic property of reversible combination with oxygen is lost when the globin moiety is denatured and, furthermore, the coordination of denatured globin with haem gives rise to a group of "haemochrome" derivatives with very characteristic spectra.

In relation to the study of abnormal haemoglobins in hereditary anaemias, the most important denaturation reaction that has been used up to the present time is the conversion of $\mathrm{HbO}_{2}$ into alkaline haematin by alkali at $p \mathrm{H}$ values in the region of 11.5 to 13 . Körber (1866) noted that human foetal $\mathrm{HbO}_{2}$ was much more resistant to alkali than adult $\mathrm{HbO}_{2}$ and Krüger $(1888,1925)$ utilized this same reaction to reveal differences between the haemoglobins of various species. Subsequent work along the same lines has been summarized by Haurowitz and Hardin (1954), and the more recent application to the study of abnormal human haemoglobin mixtures is discussed below. Havinga and Itano (1953) have noted differences in the rate of splitting of globin from $\mathrm{Hb}-\mathrm{S}$ and $\mathrm{Hb}-\mathrm{A}$ respectively but no analytical use has yet been made of this finding. Other denaturation reactions that have been studied in the case of $\mathrm{Hb}-\mathrm{A} / \mathrm{Hb}-\mathrm{F}$ mixtures are briefly noted below.

The fact that SH groups are either unblocked or formed in denaturation is of interest in the light of Ingbar and Kass's (1951) observation that Hb-S contains one more titratable SH group per mole of haemoglobin than $\mathrm{Hb}-\mathrm{A}$; this difference is not retained in $20 \%$ methanol in which some degree of denaturation seems to occur.

\section{Amino-acid Composition of Globin}

Vertebrate globins are remarkable in containing a very high percentage of histidine $(7.8-8.6 \%$; Roche, 1936). This contributes to their basic character, and the invertebrate haemoglobins, containing less histidine, are also less basic (Roche, 1936). The imidazole groups are thought to be of fundamental importance in coordination of the haem iron atoms (Wyman, 1948).

Detailed amino-acid analyses are not numerous. Tristram $(1949 a, b)$ has critically summarized the data for horse myoglobin and haemoglobin, and considers that the two proteins differ significantly in composition. The numbers of residues are not simple multiples of 4 , suggesting variation in the sub-units. Sulphur amino-acids are low and in native globin the sulphydryl groups appear relatively non-reactive, though reacting with some reagents on denaturation (see Haurowitz and Hardin, 1954). Free $\alpha$-amino groups are numerous (Chibnall, 1942), and the end-group analyses of Porter and Sanger $(1948,1949)$ reveal five terminal valine residues for adult human haemoglobin and 43 free $\epsilon$-amino-groups of lysine. These data are of importance in considering the $\mathrm{x}$-ray evidence for 
folding of the polypeptide chain within the haemoglobin molecule (Perutz, 1949).

The significance of variation in amino-acid composition will be considered further in connexion with foetal and sickle-cell haemoglobins. From the results of their analyses on various mammalian haemoglobins, including adult and foetal forms, Porter and Sanger (1948) attach considerable importance to the parallel between antigenic specificity and the number of valyl end-groups, and hence the configuration of the polypeptide chain.

\section{Immunological Properties of Haemoglobin}

Haemoglobin is a poor antigen and its properties in this respect were once the subject of much debate. The non-antigenic properties of the haem moiety and the extent of the species specificity of various haemoglobins have now been established (Marrack, 1938; Landsteiner, 1945; references and reviews). In view of these findings many attempts have been made to utilize the delicacy and specificity of immunological techniques for differentiation of the various types of abnormal haemoglobins encountered in the hereditary anaemias. As noted below the immunological identification of $\mathrm{Hb}-\mathrm{A}$ and $\mathrm{Hb}-\mathrm{F}$ has been achieved by many workers, but the antigenic character of $\mathrm{Hb}-\mathrm{S}$ does not differ very markedly from that of $\mathrm{Hb}-\mathrm{A}$. Hb-C and Hb-D do not appear to have been studied.

In this connexion it should be noted that some workers have obtained antisera containing agglutinins to erythrocytes containing $\mathrm{Hb}-\mathrm{F}$ and $\mathrm{Hb}-\mathrm{S}$ by using such cells as antigens. In view of the lack of information on possible differences in the membrane and stromal proteins of erythrocytes containing abnormal haemoglobins it seems necessary at this stage of our knowledge of the subject to envisage the possibility that the antigenic response of the various haemoglobins and of the intact erythrocytes carrying them may be different. This possibility is mentioned by Ikin, Lehmann, and Mourant (1953).

\section{The Solubility of Haemoglobin}

The solubility of proteins is very sensitive to such factors as the concentration of neutral salts present and the $p \mathrm{H}$. According to the concentration of salts present the minimal solubility occurs at a $p \mathbf{H}$ value more or less close to the iso-electric point of the protein, where the amphoteric molecule exhibits an overall electric neutrality. The effect of electrolytes is particularly related to their ionic strength, which was formulated by Debye (1923) and Debye and Hückel (1923) as half the sum of all the terms obtained by multiplying the molar concentration of each ion by the square of its own valence. A very full treatment of the physical chemistry of protein solubility is given in the monograph by Cohn and Edsall (1943).

In 1925, Cohn showed that the solubility of haemoglobin and other proteins in concentrated ammonium sulphate solutions could be expressed in linear form by plotting log solubility against ionic strength:

$$
\log S=\beta^{\prime}-K_{S}^{\prime}(r / 2)
$$

where $\mathrm{S}$ is solubility in $\mathrm{g} / \mathrm{l}, \mathrm{K}_{\mathrm{s}}^{\prime}$ the salting-out constant, $\mathrm{r} / 2$ ionic strength and $\beta^{\prime}$ the extrapolated intercept of the linear portion of the curve on the ordinate axis $(\log S)$. Haemoglobin solubility in various salt solutions is only linear over a range of high ionic strengths and closely resembles cystine in behaviour (Cohn, 1936). The salting-out constant $\mathbf{K}^{\prime}{ }_{s}$ is independent of $p \mathbf{H}$ and temperature for a given salt and protein, whereas $\beta^{\prime}$ is markedly influenced and reflects the amphoteric properties of the protein. Green (1931) obtained series of parallel lines when $\log \mathrm{S}$ was plotted against $\mathrm{r} / 2$ for horse $\mathrm{HbO}_{2}$ and $\mathrm{HbCO}$ at varying temperatures, and similarly at varying $\mathrm{pH}$; at $0^{\circ} \mathrm{C}$. horse $\mathrm{HbCO}$ is about 25 times more soluble than at $25^{\circ} \mathrm{C}$. at high $\mathrm{r} / 2$, but at low salt concentrations solubility increases with temperature.

Green, Cohn, and Blanchard (1935) studied the solubility of human and horse $\mathrm{HbCO}$ in concentrated phosphate buffers, and found such marked differences as to distinguish the two proteins completely. Human $\mathrm{HbCO}$ was far more soluble, and both $\beta^{\prime}$ and $\mathrm{K}_{\mathrm{s}}^{\prime}$ were greater. Jope and O'Brien (1949) have carried out solubility studies of the type described on human foetal and adult haemoglobins. $\mathrm{HbCO}$, crystallized from adult blood, behaved as a single component when increasing amounts of the solid phase were mixed with $2 \mathrm{M}$ phosphate at $p \mathrm{H}$ 6.7. At this $p \mathbf{H}$, adult $\mathrm{HbO}_{2}, \mathrm{HbCO}$, and methaemoglobin had rather similar solubilities and obeyed the Cohn equation over the range of $r / 2$, 4 to 6 . On the other hand, reduced haemoglobin was far less soluble; in the range $r / 2,3.5$ to 4.5 , solubility was linear. Amorphous $\mathrm{HbCO}$ was more soluble than crystalline as found for other species by Roche, Derrien, and Moutte (1941), and higher solubilities were obtained by dissolving up HbCO than by salting out.

Jope and O'Brien (1949) observed solubility differences between reduced $\mathrm{Hb}$ and the isomorphous derivatives $\mathrm{HbO}_{2}, \mathrm{HbCO}$, and methaemoglobin with respect to the effect of temperature. Haemoglobin did not vary in solubility with temperature, whereas the latter three had temperaturesolubility curves with minima at about $20^{\circ} \mathrm{C}$. Dis- 
tinction between foetal and adult $\mathrm{HbO}_{2}$ was also apparent in this respect; the solubility of foetal

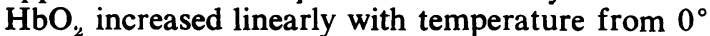
to $25^{\circ} \mathrm{C}$., resembling the behaviour of many proteins in dilute salt solutions. Foetal reduced Hb was only slightly more soluble than adult, and similarly was unaffected by temperature.

The distinctions established by solubility measurements have recently acquired great practical importance, particularly with regard to the haemoglobin abnormality in sickle-cell anaemia. Roche and Derrien (1953) have discussed the analysis of human haemoglobins by the study of solubility behaviour, with particular reference to fractional salting-out procedures.

\section{The Shape of the Haemoglobin Molecule}

Riley and Herbert (1950) have applied low-angle scattering of $x$-rays to concentrated human haemoglobin solutions, and their results suggest that the unhydrated molecules are squat cylinders or spheres, which are close-packed in concentrated solution and surrounded by a single layer of boundwater 3A thick. Dielectric constant studies are consistent with the molecule in solution being ellipsoidal (Wyman, 1948).

Using the method of $x$-ray diffraction by single crystals, Bragg and Perutz and their colleagues have obtained a considerable body of information on the form of the haemoglobin molecules from a number of mammalian species (Bragg and Perutz, 1952a and b; Bragg, 1952, 1953). Ellipsoidal in form, the haemoglobin molecule is about $60 \times$ $40 \times 40$ A dry, but when hydrated the layer of bound water increases the dimensions to $65-70 \times$ $55 \times 55 \mathrm{~A}$ and the volume to $115,000 \mathrm{~A}^{3}$. Determination of the molecular form was achieved by suspending horse methaemoglobin crystals in various strengths of salt solutions. These penetrated into the unit cells but not into the hydrated molecules, and the resulting density changes reduced the intensity of the lower orders of diffraction; the amplitude changes then depend on the form of the molecule.

The $x$-ray diffraction data have also indicated that the polypeptide chains run parallel to the long, or a-axis of the molecule. The chains have been visualized end-on for horse methaemoglobin (Bragg, Howells, and Perutz, 1952), and probably lie in three heavy inner layers and two lighter outer layers. There is evidence that the polypeptide chains are coiled into cylindrical rods possessing the $\alpha$-helix structure, that they do not run throughout the length of the molecule but are split by the haems into two parts of average length about $25 \mathrm{~A}$, and that the chains turn corners after running straight for about one quarter the length of the molecule (see Perutz, 1952; Crick, 1952; Pauling, 1953).

The haem groups appear to lie on the surface of the haemoglobin molecule, roughly normal to the polypeptide chains and parallel to one another, particularly in reduced haemoglobin. Their strongly absorbing character confers pleochroic properties on the molecules and crystals, plane polarized light being most strongly absorbed when it vibrates with its electric vector parallel with the plane of the flat haem molecules. Perutz (1939, 1952,1953 ) has made considerable use of the pleochroism of haemoglobin derivatives in his crystallographic studies. Keilin (1953) has recently reviewed the chemical evidence that the haem groups probably lie in readily accessible positions on the surface of the molecule.

\section{Crystallography of Human Haemoglobin}

It has long been known that human haemoglobin and its derivatives could be crystallized, but recent studies have included thorough examination by the polarizing microscope and by $x$-ray diffraction.

Drabkin $(1945,1946)$ obtained bipyramids of human oxy-haemoglobin and assigned them to the tetragonal class from their optical properties. This has been confirmed by $\mathrm{x}$-ray diffraction studies, the space group being $\mathrm{P}_{1} 2_{1}$ (Perutz, Liquori, and Eirich, 1951; Bragg and Perutz, 1952a).

Jope and O'Brien (1949) have also crystallized adult $\mathrm{HbO}_{2}, \mathrm{HbCO}$, and methaemoglobin under different conditions, and shown them to be isomorphous, and to belong to the orthorhombic system. Reduced haemoglobin yields different crystals, of the monoclinic system. All these findings have also been confirmed by $x$-ray diffraction studies (Perutz and Weisz, 1947; Bragg and Perutz, 1952a).

Human foetal haemoglobin is crystallographically distinct from the adult pigment (Perrier and Jannelli, 1931; Haurowitz, 1935). Jope and O'Brien (1949) found that foetal $\mathrm{HbO}_{2}, \mathrm{HbCO}$, and methaemoglobin were isomorphous, but probably monoclinic. The reduced haemoglobin was also distinct, and Kendrew (1949) confirmed the difference between adult and foetal types by $x$-ray diffraction. Kendrew and Perutz (1948) carried out detailed $x$-ray diffraction analysis on adult and foetal haemoglobins of the sheep. The results indicated considerable structural differences between adult and foetal forms (Bragg and Perutz, 1952a). 


\section{FOETAL HAEMOGLOBIN}

It will be clear from the foregoing discussion that numerous differences may be found between adult and foetal haemoglobins in a number of species. These differences have attracted particular attention in man, in relation to the occurrence of a foetal-type haemoglobin in post-natal red cells in various pathological states.

The haem moiety of the two forms of pigment is the same, the differences concerning the structure of the globin and perhaps also the haem-globin linkages. To some extent the establishment that adult and foetal haemoglobins are not identical is a general facet of the problem of molecular individuality of globular proteins, but the relative ease of crystallization of these haemoglobins and certain of their unique properties render the experimental approach easier.

The differences between adult and foetal haemoglobins have been discussed by Lecks and Wolman (1950), and the following list is modified from their review: (a) Crystallographic differences ; $(b)$ solubility differences ; $(c)$ differences in amino-acid composition ; $(d)$ immunological specificity ; $(e)$ greater stability of foetal haemoglobin towards alkali denaturation; $(f)$ rate of spreading in surface films ; (g) electrophoretic mobilities; (h) spectrophotometric differences in the ultra-violet region of the spectrum; (i) differences in oxygen dissociation curves; $(j)$ clinical significance of foetal-type haemoglobin. Kendrew (1949) and Zinnser (1952) also note these differences.

\section{Crystallographic Differences}

These have already been discussed. In the case of adult and foetal sheep haemoglobins, the results of $x$-ray diffraction studies indicate fundamental molecular differences between the two pigments (Kendrew and Perutz, 1948 ; Bragg and Perutz, 1952a).

\section{Solubility Differences}

The careful studies of Jope and O'Brien (1949) reveal the differences between solubility behaviour of adult and foetal forms of the isomorphous $\mathrm{HbO}_{2}, \mathrm{HbCO}$, and methaemoglobin derivatives, and the reduced haemoglobins respectively. The reduced haemoglobins are far less soluble than the isomorphous derivatives for both adult and foetal pigments, but the foetal reduced pigment is more soluble than the adult. Itano (1953c) found that standard quantities of preparations containing foetal haemoglobin from newborn infants or from patients with thalassaemia major were more soluble in strong phosphate buffer than adult haemoglobin.
Karvonen (1949) found that the solubility of mixtures of adult and foetal sheep haemoglobins was more than additive, but subject to rather complex physical effects; abrupt reduction in solubility occurred when the protein concentration was increased beyond the onset of crystallization.

The studies of Wyman, Rafferty, and Ingalls (1944) on the solubilities of adult and foetal bovine $\mathrm{HbCO}$ in strong phosphate buffers at $p \mathrm{H} 6.8$ indicated that the latter protein is more than six times more soluble than the former over the range of ionic strength 4.9 to 5.5 .

\section{Differences in Amino-acid Composition}

A number of earlier analyses of the amino-acids of various haemoglobins yielded somewhat variable results (see Lemberg and Legge, 1949, for literature), but Vickery (1944) found that the histidine content of crystalline foetal bovine $\mathrm{HbCO}$ was significantly lower $(6.43 \pm 0.04 \%)$ o than that of the adult pigment $(6.81 \pm 0.05 \%)$, as determined by the dichlorobenzenesulphonate method.

Using the 1:2:4-fluorodinitro-benzene reagent for free amino groups in proteins, Porter and Sanger (1948) found five terminal valine residues and 43 free lysine -amino groups in adult human haemoglobin; the foetal pigment contained an average of only 2.6 terminal valine groups, and 47 free lysine $\epsilon$-amino groups. This probably indicates the presence of two valyl end-groups in the foetal molecule, since some adult haemoglobin occurred in even the earliest, 30-week foetal samples examined spectrophotometrically and electrophoretically by Beaven, Hoch, and Holiday (1951).

Van der Linden (1949) applied microbiological assay methods to the analysis of human globins and found significant differences in composition between newborn and children's ( 6 months -2 years) globins with respect to seven amino-acids, viz, histidine, iso-leucine, threonine, methionine, proline, tyrosine, and valine; the greatest differences were found for iso-leucine. The same children's bloods compared with adult bloods showed small but significant differences in glutamic acid, methionine, and leucine, pointing to a difference in composition of these two forms of $\mathrm{Hb}-\mathrm{A}$.

\section{The Immunological Specificity of Foetal Human Haemoglobin}

The antigenic specificity of the globin in haemoglobins from different animals has been studied extensively (Heidelberger and Landsteiner, 1923 ; Hektoen and Schulhof, 1923; Hektoen and Boor, 1931), and the difference between human foetal and adult forms was demonstrated clearly by 
Darrow, Nowakovsky, and Austin (1940). Porter and Sanger (1948) consider that there is a relationship between the terminal amino-acid residues and immunological specificity.

Schneider and Levin (1950) obtained rabbit antisera giving specific agglutination of sickle-cell anaemia erythrocytes but not of sickle-cell trait erythrocytes. Ikin et al. (1953) pointed out that Schneider and Levin may have been using antisera which specifically agglutinated cells containing $\mathrm{Hb}-\mathrm{F}$ and not $\mathrm{Hb}-\mathrm{S}$, as the former appears to be present in relatively small proportions in sicklecell anaemia whereas it is absent from the sicklecell trait condition.

Goodman and Campbell (1953) obtained evidence for antigenic differences between $\mathrm{Hb}-\mathrm{A}$ and $\mathrm{Hb}-\mathrm{S}$ using chicken antisera under conditions of maximal precipitation. They concluded that these two haemoglobins both possess a large number of common antigenic determinant groups, but that each carries a small number of such groups that are unique for each type of haemoglobin.

Relatively large differences in specificity were found to exist between $\mathrm{Hb}-\mathrm{A}$ and $\mathrm{Hb}-\mathrm{F}$ indicating that only a few antigenic determinan $\hat{\imath}$ groups are common to this pair of haemoglobins. The immunological behaviour of the minor haemoglobin of sickle-cell anaemia blood was shown to be very similar, if not identical with that of Hb-F, in agreement with the indications that this component is in part at least $\mathrm{Hb}-\mathrm{F}$.

Chernoff (1953a) obtained rabbit antisera to haemoglobin solutions prepared from normal adult, cord blood, and sickle-cell anaemia erythrocytes. An anti-Hb-F serum was also prepared using $\mathrm{Hb}-\mathrm{F}$ freed from $\mathrm{Hb}-\mathrm{A}$ by partial alkaline denaturation, and appeared to be specific for Hb-F. No such specificity was found between the anti-Hb-A and anti-sickle-cell anaemia sera. This lack of specificity was suggested to be due to the presence of $\mathrm{Hb}-\mathrm{F}$ in varying amounts in all the antigens used and hence of $\mathrm{Hb}-\mathrm{F}$ precipitins in all the antisera. In a second paper (1953b) the immunological detection of $\mathrm{Hb}-\mathrm{F}$ by means of a specific anti-Hb-F serum was put on a quantitative basis and used to detect traces of (up to $1 \%$ ) $\mathrm{Hb}-\mathrm{F}$ in normal aduli bloods. Comparable or larger proportions of $\mathrm{Hb}-\mathrm{F}$ were similarly detected in bloods from a large number of haematological conditions and confirmed by parallel estimations of alkali-resistant haemoglobin. Chernoff concluded that the minor haemoglobin constituent observed in these conditions was indeed $\mathrm{Hb}-\mathrm{F}$ rather than an abnormal "foetal-like" $\mathrm{Hb}$. It may be noted that these most interesting findings depend on both the immunological and denaturation rate methods of detecting $\mathrm{Hb}-\mathrm{F}$ being sensitive to this component in proportions of much less than $10 \%$, a level at which other methods for detecting $\mathrm{Hb}-\mathrm{F}$ are of little value. The unequivocal confirmation of all Chernoff's findings may therefore be difficult.

Ikin et al. (1953) obtained rabbit sera containing agglutinins to human cord and newborn red cells by using cord blood erythrocytes as antigen. (Anti-human species agglutinins were removed by absorption, the resulting sera being almost inactive against adult human cells.) Their results show that the specific agglutination reaction with infant erythrocytes becomes negligible after four and a half months, in fair agreement with other estimates of the persistence of $\mathrm{Hb}-\mathrm{F}$ after birth. In connexion with the various suggestions (Chernoff, 1953a and b ; Goodman and Campbell, 1953) that small proportions of $\mathrm{Hb}-\mathrm{F}$ are present in normal adults, it is of great interest that Ikin et al. obtained weakly positive results with six out of 20 normal adult control bloods.

\section{Alkali-denaturation of Adult and Foetal Haemoglobins}

The estimation of Hb-F in haemoglobin mixtures by the alkaline denaturation rate method has been the subject of many variations in technique. All procedures are based on the reasonable assumption that in the presence of excess reagent $\left(\mathrm{OH}^{-}\right) \mathrm{Hb}-\mathrm{A}$ and $\mathrm{Hb}-\mathrm{F}$ are both transformed independently into alkaline haematin by kinetically first-order reactions so that the overall course is the result of two separate rate curves; the steep initial part of the curve is largely controlled by the fast denaturation of $\mathrm{Hb}-\mathrm{A}$ and the less steep terminal part by the slow change of $\mathrm{Hb}-\mathrm{F}$. Either pure haemoglobin gives a simple rate curve which is linear on a semi-logarithmic plot $\left(\because\right.$ unchanged $\mathrm{HbO}_{2}$ against time), while a mixture gives a semi-logarithmic plot which may be linear initially and finally with a curved intermediate section of extent depending on the composition of the mixture. Extrapolation of the terminal linear portion of the semi-logarithmic plot back to zero time cuts the composition axis at the $\mathrm{Hb}-\mathrm{F}$ content of the mixture.

Depending on the analytical method used and the $p \mathrm{H}$ (which greatly effects the absolute reaction rates) various workers have determined the entire reaction curve, starting as near as possible to zero time and extending to $100 \%$ reaction (Brinkman, Wildschut and Wittermans, 1934: Brinkman and Jonxis, 1935, 1936; Jonxis, 1949; Betke, 1951; Beaven and White, 1953, and this review, Fig. 1; Baar and Lloyd 1943). The extrapolation to find the proportion of Hb-F is then independent of the 


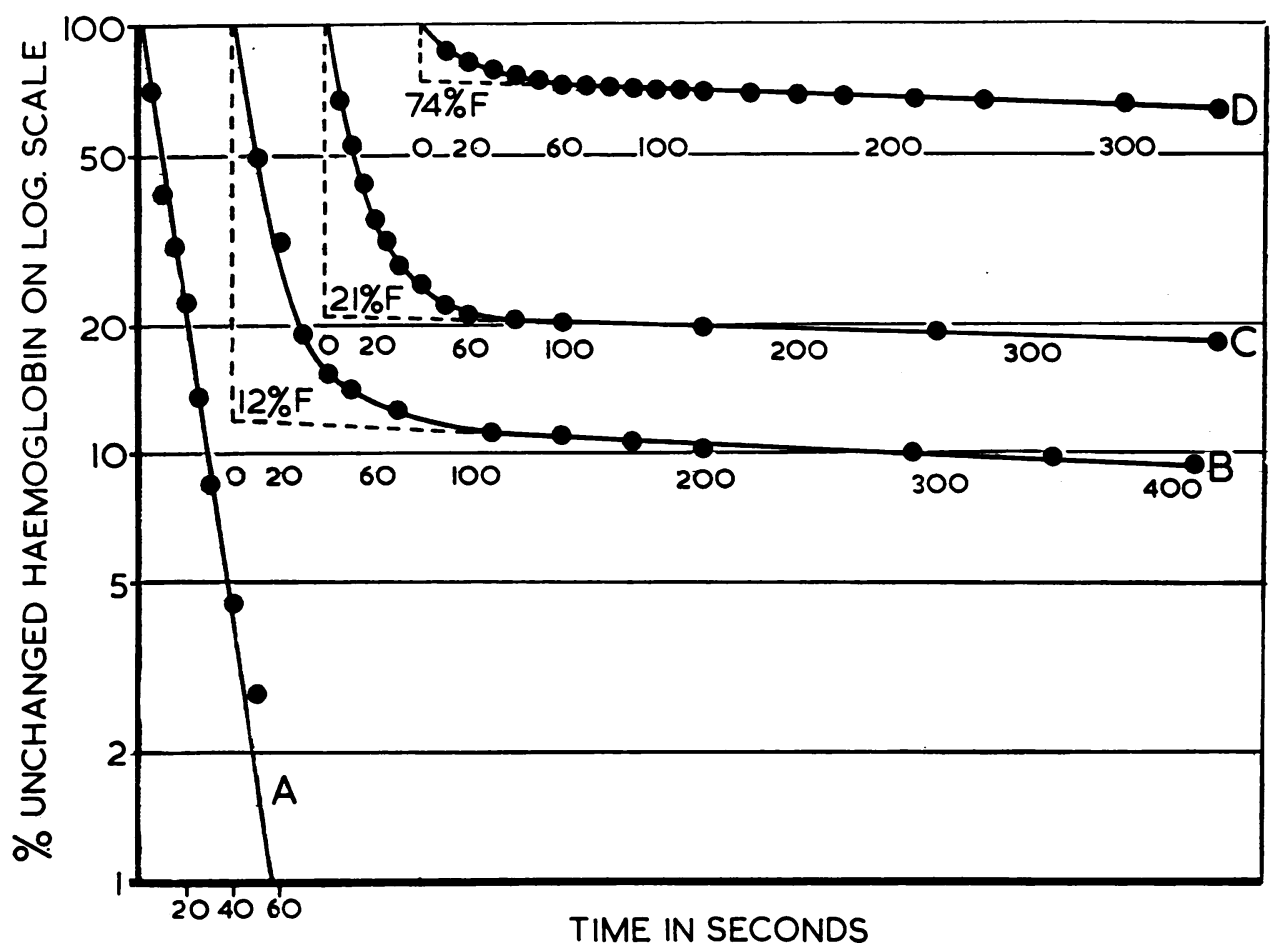

Fig. 1.-Rates of denaturation of adult and foetal haemoglobins in $0.04 \mathrm{~N} . \mathrm{NaOH}$ at $20^{\circ}$ expressed as first-order reaction. $A$ is the sickle-cell trait, and no $\mathrm{Hb}-\mathrm{F}$ is present. $\mathrm{B}$ is Mediterranean anaemia with $12 \% \mathrm{Hb}-\mathrm{F}$ present. $\mathrm{C}$ is sicklecell anaemia in a child of 1 year with $21 \% \mathrm{Hb}-\mathrm{F}$ present. $\mathrm{D}$ is cord blood from a normal infant at term with $74 \%$ $\mathrm{Hb}-\mathrm{F}$ present.

absolute rate of the overall reaction and hence of small changes in $p \mathrm{H}$ and temperature.

Alternatively, the reaction rates for $\mathrm{Hb}-\mathrm{A}$ and $\mathrm{Hb}-\mathrm{F}$ differ so markedly (by a factor of about 100 ) that it is possible to select a reaction period during which only the Hb-A has been completely denatured, so that the residual haemoglobin is all of the foetal type, and is esentially equal to the total $\mathrm{Hb}-\mathrm{F}$ in the sample. For a $p \mathrm{H}$ of about 12.7 (N/12 alkali) and temperature of $20^{\circ}$, a period of one minute is convenient (Singer, Chernoff, and Singer 1951a) after which the alkaline haematin is precipitated and the unchanged $\mathrm{Hb}-\mathrm{F}$ in the supernatant estimated colorimetrically or spectrophotometrically (at $540 \mathrm{~m} \mu$ ) to give a " one minute denaturation value ".

In a variant of this procedure Ponder and Levine (1949), working at $p \mathrm{H} 12.15$ and $26^{\circ} \mathrm{C}$. in an alkaliglycine buffer, precipitated separate replicates of the reaction mixture at periods ranging from 10 to 80 mins. from the start, and by estimating unchanged $\mathrm{HbO}_{2}$ in the filtrates with a photoelectric colorimeter, obtained five points covering the course of the reaction which could be used to give a linear semi-logarithmic plot (except the $10 \mathrm{~min}$. point). This could be extrapolated to zero time in the usual way to give the Hb-F content of the sample. With this "five-point" method results on artificial mixtures of $\mathrm{Hb}-\mathrm{A}$ and $\mathrm{Hb}-\mathrm{F}$ were within $4 \%$ of the calculated values and agreed to $\pm 5 \%$ with values obtained from the complete reaction curve method used by Baar and Lloyd (1943).

Singer et al. (1951b) similarly modified their " one-minute test" to give a " fractional denaturation " curve by the successive sampling of eight to 10 reaction replicates over periods depending on the $\mathrm{Hb}-\mathrm{F}$ content, estimated by preliminary oneminute tests. These workers pointed out that the fractional denaturation method was relatively inexact and could be used for finding the slope of the denaturation of the alkaline-resistant component (which is directly related to the first order rate constant) only if a sufficiently linear semi-logarithmic plot was obtained. Only about one-third of the sickle-cell anaemia haemoglobins examined by these workers gave denaturation slopes for the alkaline-resistant component comparable with the range of slopes established for authentic $\mathrm{Hb}-\mathrm{F}$.

It is unfortunate that the more stable $\mathrm{HbCO}$ form of haemoglobin is not suitable for alkaline 
denaturation studies, although it has been widely employed in electrophoretic studies. In alkali $\mathrm{HbCO}$ is eventually transformed into a haematinlike pigment but the reaction is not susceptible to a simple first-order kinetic treatment (Beaven and White, unpublished work). Methaemoglobin reacts very rapidly at $p H \quad 12-13$ to form alkaline haematin, and a small proportion of methaemoglobin in a haemoglobin sample can often be detected by an abnormally rapid rate of change of absorbance during the first few seconds of the reaction, and by a semi-logarithmic plot which does not extrapolate through the $100 \% \mathrm{HbO}_{2}$ ordinate at zero time. A simple graphical correction can be applied if necessary.

Gardikas, Scott, and Wilkinson (1953) sought other denaturing reagents which might differentiate between $\mathrm{Hb}-\mathrm{A}$ and $\mathrm{Hb}-\mathrm{F}$, and found that in 4.4 $M$ urea foetal methaemoglobin denatured more rapidly than adult methaemoglobin while in sodium salicylate solution the relative stabilities were reversed. An approximate kinetic analysis of their results (Beaven, unpublished) indicates that with urea successive reactions occur, making the method difficult to apply analytically. Betke (1951) was unable to follow the alkaline denaturation of reduced haemoglobin by the simple absorptiometer method applicable to $\mathrm{HbO}_{2}$. At the present time, therefore, the alkaline denaturation of $\mathrm{HbO}_{2}$ itself is the most practicable chemical method for the estimation of $\mathrm{Hb}-\mathrm{F}$ (see also Baar and Hickmans, 1941-42).

It is not essential to use a precipitation method to analyse mixtures of unchanged $\mathrm{HbO}_{2}$ and alkaline haematin. Their absorption spectra are sufficiently different to permit a direct spectrophotometric analysis using a wavelength of about 630 $\mathrm{m} \mu$ where the absorbance at equal molar concentrations is optimal for the denaturation product. Alternatively a deep red filter with a pass-band centred around this wavelength is adequate and has been used by many workers in conjunction with commercial photoelectric absorptiometers of conventional design (e.g. Baar and Lloyd, 1943). It is also possible to work at about 540 to $580 \mathrm{~m} \mu$ or to use a corresponding green filter, in which case the absorbance of the systems falls with the progress of denaturation due to decreasing absorption by $\mathrm{HbO}_{2}$ (e.g. Larsen, 1951). In our experience, the use of a simple commercial absorptiometer with a deep red filter to measure the complete reaction curve gives excellent linear plots for samples containing no Hb-F. Good terminal plots are obtained when $\mathrm{Hb}-\mathrm{F}$ is present (Fig. 1) from which the proportion of this component can be found by extrapolation to about $\pm 5 \%$. The method is sensitive to about $7 \%, \mathrm{Hb}-\mathrm{F}$ with certainty, and the presence of not less than 2 to $5 \%$ can be inferred $\frac{\text { os }}{9}$ from the "tailing" it produces in the terminal part of the plot. At $p \mathrm{H} 12.8(\mathrm{~N} / 25$ alkali) and room temperatures the half-reaction times $\left(t_{z}\right)$ for $\frac{\bar{m}}{\sqrt{\alpha}}$ $\mathrm{Hb}-\mathrm{A}$ and $\mathrm{Hb}-\mathrm{F}$ are about 10 and 1,000 secs. res- $\mathbb{\varnothing}$ pectively as recorded by earlier workers for this order of $p \mathrm{H}$. In view of the lack of sensitivity of $\stackrel{\infty}{\infty}$ the alkaline denaturation method for bloods con-. taining less than about 2 to $5 \%$ of $\mathrm{Hb}-\mathrm{F}$, and the $\overrightarrow{\vec{\omega}}$ similar limitations of the ultra-violet spectrographic $\stackrel{\circ}{\circ}$ methods at this $\mathrm{Hb}-\mathrm{F}$ level, it seems unwise to $\overline{ }$ attach any great significance to reports of traces of $v$ $\mathrm{Hb}-\mathrm{F}$ in various haematological conditions until $\omega$ these findings can be confirmed using analytical $\vec{v}$ methods of increased sensitivity and precision.

\section{Monomolecular Films of Adult and Foetal Haemoglobins}

Proteins may be spread on the surface of water $\stackrel{5}{\oplus}$ or dilute salt solutions to form monomolecular $\vec{\oplus}$ layers, the structure of which can give information of on molecular size and form (see Sobotka, 1944). Stable monomolecular films of maximal area form 0 in the neighbourhood of the iso-electric points of proteins, and Brinkman and Jonxis $(1935,1936) \overline{0}$

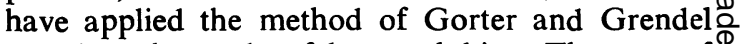
(1926) to the study of haemoglobin. The area of $\cong$ spreading on the surface of $\mathrm{M} / 300$ phosphate $\overrightarrow{\overrightarrow{0}}$ buffers over the range $p \mathrm{H} 6$ to 8 was measured, and 3 plotted as area of film per mg. of protein after one minute against $p \mathrm{H}$. Foetal and adult haemo-? globins differed, the foetal form spreading more slowly than the adult and the maximal area being: achieved at $p \mathrm{H} 6.7$ instead of 6.9. These differ-3. ences are reversed in foetal and adult haemoglobins of the cow, sheep, and goat, as is their resistances to alkali (Jonxis, 1949).

\section{Electrophoresis of Foetal Haemoglobin}

Andersch, Wilson, and Menten (1944) studied N newborn infant and adult $\mathrm{HbCO}$ in $p \mathrm{H} 7.1,0.2 \mathrm{M}_{\text {N }}^{\text {. }}$ phosphate buffer and obtained a distinct separation of $\mathrm{Hb}-\mathrm{A}$ and $\mathrm{Hb}-\mathrm{F}$ and measured their mobilities. $\omega$ They were able to detect the small proportion of surviving $\mathrm{Hb}-\mathrm{F}$ in a 90-day infant bloodo Andersch et al. discussed the evidence due too Brinkman et al. and the results of earlier studies which pointed to the heterogeneity of adult human haemoglobin, and attempted to confirm this point by electrophoretic analysis; one adult blood studied? by them showed a minor component with a mobility approaching that of $\mathrm{Hb}-\mathrm{F}$.

Andersch and his colleagues also observed a large difference by a factor of about 2 between the sedio 
mentation constants of $\mathrm{Hb}-\mathrm{A}$ and $\mathrm{Hb}-\mathrm{F}$ in the ultracentrifuge. Assuming identical diffusion constants, the difference corresponds to a molecular weight for $\mathrm{Hb}-\mathrm{A}$ about twice that of $\mathrm{Hb}-\mathrm{F}$.

Hoch $(1949,1950)$ devised conditions for the electrophoretic testing of protein homogeneity and the detection of small differences in mobility. These conditions were utilized by Beaven et al. (1951) for analysing foetal and early infant human haemoglobins. Using a differential method (Hoch, 1949) the anodic mobility of $\mathrm{Hb}-\mathrm{A}$ was found to be greater than that of $\mathrm{Hb}-\mathrm{F}$ at both $p \mathrm{H} 7.1$ and 8.0. Analyses of mixtures were made in $0.01 \mathrm{M}$ $\mathrm{Na}_{2} \mathrm{HPO}_{4}$; a low ratio of ionic strength: protein concentration, resulting in pronounced boundary anomalies, is favourable for showing up small proportions of a faster component as in the case of small amounts of $\mathrm{Hb}-\mathrm{A}$ in foetal bloods (Hoch, 1950). By working under these carefully selected conditions Beaven et al. (1951) found the Hb-A content of foetal blood to be at least $6 \%$ at 20 weeks' foetal age, about $20 \%$ at birth, about $50 \%$ at two months and $80-90 \%$ at four months after birth. The ultra-violet absorption spectral difference between $\mathrm{Hb}-\mathrm{A}$ and $\mathrm{Hb}-\mathrm{F}$ discovered by Jope (1949) was utilized in this work to provide confirmatory analyses of bloods rich in Hb-F.

Rich (1952) successfully used somewhat similar conditions to analyse mixtures of $\mathrm{Hb}-\mathrm{A}$ and $\mathrm{Hb}-\mathrm{F}$ (as $\mathrm{HbCO}$ ) in a study of Mediterranean trait and Cooley's anaemia, and confirmed Liquori's finding (1951) that $\mathrm{Hb}-\mathrm{F}$ is present in Cooley's anaemia; in two of Rich's cases the $\mathrm{Hb}-\mathrm{F}$ contents were nearly $100 \%$. For newborn infant blood Rich found about $20 \% \mathrm{Hb}-\mathrm{A}$ in agreement with other workers.

Zinsser (1952) achieved the separation of $\mathrm{Hb}-\mathrm{A}$ and $\mathrm{Hb}-\mathrm{F}$ in phosphate buffer of higher ionic strength by using long periods of electrophoresis (15-20 hrs.), such as were employed with success in the study of sickle-cell haemoglobins (Pauling et al., 1949). Zinsser obtained values for the mobilities of $\mathrm{Hb}-\mathrm{A}$ and $\mathrm{Hb}-\mathrm{F}$ at $p \mathrm{H} 6.94$ to 7.00 , and also observed differences between these two types of $\mathrm{Hb}$ with respect to (i) the change in mobility $\mathrm{HbCO}$ to $\mathrm{Hb}$; (ii) the influence of various buffer ions on mobility: (iii) the effect of caprylate ion in producing a colourless component (not due to haem displacement), and (iv) the number of globin components after haem-removal by acid treatment.

Waris (1954) used the micro-electrophoresis apparatus of Antweiler $(1949,1952)$ to examine human haemoglobins from normal adults, newborn infants, and various types of anaemias in a variety of buffers at various $p \mathrm{H}$ values. He was unable to obtain an unequivocal separation of $\mathrm{Hb}-\mathrm{A}$ and $\mathrm{Hb}-\mathrm{F}$, and no distinct variations from the $\mathrm{Hb}-\mathrm{A}$ pattern were observed in the bloods from pernicious or other anaemias. At the highest currents used and over long periods convection effects led to splitting of the single peak. Waris's results emphasize the comments made by Hoch $(1949,1950)$ on the electrophoretic separation of proteins of nearly equal mobility, and the relative difficulty of the $\mathrm{Hb}-\mathrm{A} / \mathrm{Hb}-\mathrm{F}$ separation.

\section{Spectrophotometry of $\mathbf{H b}-\mathbf{F}$}

Jongbloed (1938) was unable to detect any difference in the ultra-violet absorption spectra of foetal and adult human haemoglobin. Lambrechts and Martin (1951) made a careful study by photoelectric spectrophotometry at $10 \mathrm{~A}$ spectral bandwidth of a large number of foetal and adult human bloods and found the wavelengths of the maxima and minima in the visible to be identical for the two groups of specimens in both the $\mathrm{HbO}_{2}$ and $\mathrm{Hb}$ states, as were the analytically important absorbence ratios to within approximately $2 \%$. They were thus able to conclude with confidence that the various methods, based on the absorption characteristics in the visible, used for the estimation of $\mathrm{Hb}$ in adult bloods, were valid for newborn infant bloods.

The moving-plate, logarithmic-cam technique, devised by Holiday $(1937,1950)$ for the accurate location of fine-structure bands in absorption spectra, enabled Jope (1949) to demonstrate that the tryptophan fine-structure band in the globin absorption band was located at significantly different wave-lengths in foetal (2898 A) and adult (2910 A) human haemoglobins; by the movingplate method the position of this fine-structure band can be found with a precision of $\pm 1 \mathrm{~A}$ under favourable circumstances. Jope also showed by measurements on very thin layers of settled cell suspensions that this difference between Hb-A and $\mathrm{Hb}-\mathrm{F}$ is also found when the haemoglobins are examined in intact erythrocytes. No such difference in the ultra-violet absorption spectra could be found for the foetal and adult haemoglobins of sheep and rat; the $2910 \mathrm{~A}$ band position was found to apply to the adult haemoglobins of several vertebrates, and it was also possible to show that in two mammalian muscle haemoglobins (myoglobins) the band was at $2900 \mathrm{~A}$, comparable with the human foetal position.

Beaven et al. (1951) applied Jope's observation to the analysis of mixtures of $\mathrm{Hb}-\mathrm{A}$ and $\mathrm{Hb}-\mathrm{F}$ as encountered in foetal, full-term and early infant bloods by constructing a calibration curve relating the position of the tryptophan fine-structure band 
to the proportion of $\mathrm{Hb}-\mathrm{F}$ in the blood sample, as found by parallel electrophoretic analysis. This spectrographic method, we have found in subsequent work, is capable of detecting $\mathrm{Hb}-\mathrm{F}$ in admixture with $\mathrm{Hb}-\mathrm{A}$ down to a level of about $10 \%$, with an average of precision of about $\pm 10 \%$ over the range 20 to $80 \% \mathrm{Hb}-\mathrm{F}$. This order of precision is useful for the examination of large numbers of bloods and the method is very rapid if the rather specialized spectrographic equipment required is available.

Rich (1952) devised an ultra-violet spectrophotometric method for the analysis of the $\mathrm{Hb}-\mathrm{A} / \mathrm{Hb}-\mathrm{F}$ mixtures, based on Jope's observation, but adapted for commercial photoelectric instruments, which are now widely available in clinical chemistry laboratories. The Rich slope method is in principle applicable over the entire range of mixture composition with an estimated precision of $\pm 6 \%$ and the results agree with electrophoretic analyses to within $7 \%$ (Rich, loc. cit.). In our experience the Rich slope method may be of greater potential utility than the Jope moving-plate method but entails very precise spectrophotometric technique and the basic calibration curve is not easy to establish with certainty.

\section{The Oxygen Dissociation Curve for Foetal Blood}

A number of investigators have established differences between the oxygen dissociation curves for foetal and adult blood, and also for the maternal blood in pregnancy. Leibson, Likhnitzky, and Sax (1936) found that the curve for the blood of normal women varied within narrow limits whilst the maternal blood in pregnancy gave a curve displaced slightly to the right, probably through increased hydrogen ion concentration. The dissociation curve for foetal blood lay to the left of that for normal women. Essentially similar results have been found by several investigators (Haselhorst and Stromberger, 1931; Eastman, Geiling, and De Lawder, 1933; Darling, Smith, Asmussen, and Cohen, 1941), and the question is discussed in detail by Barcroft (1946).

It is generally considered that the difference in behaviour of the foetal corpuscles is best accounted for by the presence of a different haemoglobin, but the situation is complicated by possible differences in ionic environment within the corpuscle, permeability and blood $p \mathrm{H}$. Haurowitz (1935) found that in dilute solution human foetal haemoglobin was unique in having a lower oxygen affinity than the maternal haemoglobin, and this reversal of the behaviour found in the corpuscles has been confirmed by Hill (see Barcroft, 1946) and by McCarthy
(1943) for strong solutions of the haemoglobin. McCarthy (1943) found that the maternal corpuscles markedly decreased the affinity of the adult $\mathrm{Hb}$, whereas the foetal cells had little effect on the foetal $\mathrm{Hb}$, thus accounting for the position when the whole bloods were compared.

In the case of the bull frog, the transition between oxygen dissociation curves of tadpole and frog is particularly weil seen. In the tadpole, the curve is hyperbolic, with efficient loading capacity for acquiring oxygen under water; the curve of the metamorphosed frog, respiring air in the lungs, is definitely sigmoid and efficient for unloading oxygen to the tissues (McCutcheon, 1936; Barcroft, 1946).

\section{Oxidation of Foetal Haemoglobin to Methaemo- globin}

An interesting question, which has been little explored, is the ease of oxidation of foetal haemoglobin to methaemoglobin. In blood of normal adults, methaemoglobin, or other pigment without oxygen-carrying power is present only to a very small extent (Ramsay, 1949; Wootton, 1950). Künzer and Savelsberg (1951) found $2.12 \%$ of methaemoglobin in the blood of suckling infants in the first three months, as against $1 \%$ in the blood of all other age groups; cord blood samples contained only $1 \%$. They suggest that this relates to low activity of the glycolytic enzyme systems which normally prevent by reduction the intracorpuscular accumulation of methaemoglobin (see Barcroft, Gibson, and Harrison, 1949). Well water containing nitrates may cause methaemoglobinaemia in infants (Comly, 1945), and Cornblath and Hartmann (1948) considered that nitrite formed by reduction by microorganisms in the gastro-intestinal tract was responsible. Lecks (1950) obtained some evidence that more ready oxidation of foetal haemoglobin by nitrites also played a part. The frequent occurrence of heavy methaemoglobinaemia in premature infants treated with sulphamezathine (Mann and O'Brien, 1951) may also indicate this. Studies are needed on systems free of enzymes, or in the presence of inhibitors.

Betke (1953) has measured the rate of oxidation of cord-blood and adult, purified haemoglobins to methaemoglobin by sodium nitrite at $p \mathrm{H} 5.5$, and found that the former is transformed at about twice the rate of the latter.

\section{Clinical Significance of Foetal Haemoglobin}

It is usual to point to the different sites of erythrocyte formation in foetus and adult in explaining the two types of haemoglobin. The liver as 
opposed to the marrow is often quoted as the principal site of origin for foetal erythrocytes (see Barcroft, 1946; Drabkin, 1951). However, foetal haemopoiesis is a complicated process, passing through several morphologically distinct phases, and widely distributed in many organs and tissues (Gilmour, 1941). The liver is the chief site in mid-foetal life, but skeletal sites appear in the clavicle of the $43 \mathrm{~mm}$. embryo (Gilmour, 1941), and the marrow progressively assumes the principal role from the fifth month of intra-uterine life onwards, and is the exclusive site from 15 to 21 days after birth (Gilmour, 1941).

The spectrophotometric data of Beaven et al. (1951) indicate a very gradual change-over from foetal to adult-type haemoglobin formation, beginning not later than the middle of intra-uterine life. Even haemoglobin from a 20-week foetus contained $6-7 \%$ adult-type $\mathrm{Hb}$, and at term about $20 \%$ was present. It is possible that the foetal-type globin is an expression of the general foetal anabolism rather than the specific site of origin. These workers found that no more than $10 \%$ of foetal haemoglobin persists four months after birth, and this would be compatible with the morphological observations of Gilmour (1941) that erythropoiesis is entirely intramedullary from 15 to 21 days after birth, but also indicates that only adult haemoglobin is formed after delivery. Other workers suggest that foetal haemoglobin disappears in the first few months of life (Trought, 1932; Haurowitz, 1935), but Singer et al. (1951a) using a denaturation test claim to have detected a small percentage persisting as long as two years after birth in healthy infants. It is clear that further correlation is required between the morphology of haemopoiesis during intra-uterine life and infancy, and the detection of foetal haemoglobin by a range of physical methods.

It has frequently been considered that foetal haemoglobin may persist after birth or reappear in various pathological conditions (see Barcroft, 1934) or modified environment conditions (e.g. in dwellers at high altitudes; Rubowitz, 1933). In pernicious anaemia, the similarities between megaloblastic haemopoiesis and the earliest, primitive generation of nucleated red cells in pre-somite embryos and also the part played by the liver have prompted several investigators to look for foetal haemoglobin. Schenck (1930) thought alkali-resistant haemoglobin occurred in this condition. Larsen (1951) also claimed that foetal haemoglobin occurred, and might be responsible for the thin macrocytes present in air-dried films of the blood; such cells did not disappear after treatment by purified liver extracts, folic acid, or vitamin B12. However, Trought (1932) and Haurowitz (1935) have found the rapid denaturation characteristic of normal adult $\mathrm{Hb}$, and Jope and O'Brien (1949) prepared orthorhombic crystals of normal adult $\mathrm{HbO}_{2}$ from pernicious anaemia blood.

A number of Italian workers have noted the presence of alkali-resistant haemoglobin in the red cells in thalassaemia major (Bianco, 1948; Putignano and Fiore-Donati, 1948; Sansome and Cusmano, 1950; Vechio, 1948). Liquori (1951) investigated the blood in thalassaemia major (Cooley's anaemia; Cooley and Lee, 1925), and obtained unequivocal evidence for the presence of a mixture of adult and foetal haemoglobins. This was indicated by the slow alkali-denaturation rate, and by the absorption method. Crystals of $\mathrm{HbO}_{2}$ were prepared with the morphology and higher solubility characteristic of the foetal pigment. Rich (1952) by the ultra-violet absorption method has consistently found large amounts of foetal haemoglobin in the blood of children with thalassaemia major whereas the parents with thalassaemia trait have the adult pigment. Genetically, Cooley's anaemia appears to be a homozygous condition inherited from heterozygous parents (Moncrieff and Whitby, 1934; Valentine and Neel, 1944), and a fundamental defect in the ability to synthesize haemoglobin occurs, the presence of foetal $\mathrm{Hb}$ being the result rather than the cause of this. In Fig. 1 the presence of foetal haemoglobin is shown in the blood of a Cypriot child with Cooley's anaemia, whose parents with Mediterranean trait have the adult pigment only. Roche, Derrien, Diacono, and Roques (1953) have studied 21 cases of different degrees of thalassaemia occurring in individuals of various racial origins (Arabs, Maltese, Sicilians) all living in Tunis. The individuals with thalassaemia minima had haemoglobin indistinguishable from normal adult haemoglobin, as studied by the solubility curves of $\mathrm{HbCO}$ in phosphate buffers and by alkali denaturation. The cases with thalassaemia minor (Rietti-GreppiMicheli disease) had 15 to $40 \%$ haemoglobin behaving like the foetal pigment in these tests, whereas the cases of thalassaemia major (Cooley anaemia) had $69-98 \%$ of foetal-type pigment.

Singer et al. (1951a) have detected foetal haemoglobin in Cooley's anaemia, in the trait in small amounts, and also they believe that small amounts of alkali-resistant pigment may occur in a variety of haematological disorders, including some cases of acute and chronic leukaemia, pernicious anaemia, leuco-erythroblastic anaemia due to secondary carcinomatosis of the marrow, chronic aregenerative anaemia, and hereditary spherocy- 
tosis; haemorrhagic and iron-deficiency anaemias have normal adult pigments only.

Haemoglobins from a series of haemolytic anaemias have been studied by Beaven and White (1953) by the alkali-denaturation method and by ultra-violet spectrophotometric methods. The series included the cases of atypical congenital haemolytic anaemia published by Dacie, Mollison, Richardson, Selwyn, and Shapiro (1953), as well as hereditary spherocytic anaemias. Despite the frequent occurrence of profoundly disturbed haemopoiesis, including the existence of extramedullary blood formation, the haemoglobin appeared to be predominantly of the adult type. In certain cases associated with the presence of sickle-cell haemoglobin, however, variable amounis of foetal haemoglobin were found (vide infra). Beaven and White (1953) failed to find foetal haemoglobin in pernicious anaemia of moderate or severe degree, or in most cases of acute or chronic leukaemia in adults and children. Acute erythro-leukaemia in a child of 2 years and subacute erythro-leukaemia in an adult were also associated with adult-type haemoglobin. On the other hand, two slowly progressing leukaemic processes in boys of 3 and 4 years respectively were associated with amounts of foetal haemoglobin which fluctuated from time to time, but reached as high as $35 \%$ of the total haemoglobin. A short series of primary and secondary polycythaemias have not yielded evidence for the presence of foetal haemoglobin.

\section{SICKLE-CELL DISEASE AND SICKLE-CELL HAEMOGLOBIN (HAEMOGLOBIN S)}

Understanding of sickle-cell disease has advanced rapidly in recent years on chemical, physical, and genetic grounds. A characteristic, abnormal haemoglobin has been recognized, playing a crucial part in the physical changes which distort the erythrocytes on reduction of oxygen tension to form the sickle cell. It is becoming clear that the formation of haemoglobin $S$ is under the control of a dominant gene, and that in the heierozygous condition this leads to formation in the erythrocytes of a mixture of normal and sickle-cell haemoglobins characteristic of the "sickle trait" or sicklaemia, whereas in the homozygous state a large excess of sickle haemoglobin occurs in the erythrocytes and the severe manifestation of sickle-cell anaemia occur. On the basis of gene-controlled haemoglobin synthesis, the gene for sickle-cell haemoglobin may interact with genes for other abnormal haemoglobins (C or D) or with the thalassaemia gene, and the affected progeny suffer a variety of haematological and haemolytic disorders related to sickle-cell disease.

The first important discovery in this field was that of Pauling et al. (1949). These workers carried out electrophoretic analysis in the Tiselius apparatus on the haemoglobins from normal individuals and from patients with sickle-cell anaemia, and found a characteristic difference in behaviour.

\section{Electrophoretic Properties of Sickle-cell Haemoglobin}

Working with both $\mathrm{HbCO}$ and $\mathrm{Hb}$ (stabilized with dithionite) in 0.1 ionic strength phosphate buffers over the $p \mathrm{H}$ range approximately 5.5 to 8.5 , Pauling et al. obtained distinctly separated plots of mobility against $p \mathrm{H}$ for normal adult and sicklecell anaemia haemoglobins, corresponding to a difference in isoelectric point of 0.22 to $0.23 \mathrm{pH}$ units

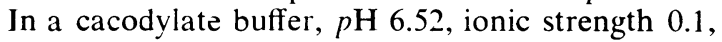
the mobility of sickle-cell anaemia $\mathrm{HbCO}$ exceeded that of normal adult $\mathrm{HbCO}$ by $0.40 \times 10^{-5}$ (units are $\mathrm{cm} .{ }^{2}$ sec. $^{-1}$ volt $^{-1}$ ). The mobility difference between $\mathrm{Hb}-\mathrm{S}$ and $\mathrm{Hb}-\mathrm{A}$ measured by Pauling et al. corresponds to two to four more net positive charges per molecule for $\mathrm{Hb}-\mathrm{S}$ in the isoelectric $p \cdot \mathrm{H}$ region.

With sicklaemia (sickle-cell trait) bloods, separation into two components, one of which was electrophoretically identical with normal adult $\mathrm{HbCO}$ and the other with that of sickle-cell anaemia, were obtained. Analyses of this two-component system, checked against artificial mixtures of normal and sickle-cell anaemia bloods, gave a figure of about $40 \%$ for the proportion of the abnormal or sicklecell haemoglobin $(\mathrm{Hb}-\mathrm{S})$ in sickle-cell trait. This figure is important for the genetic analysis of sicklecell characteristics, as it corresponds to the heterozygous condition.

In their first studies, Pauling et al. (1949) considered the haemoglobin in sickle-cell anaemia to be uniformly $\mathrm{Hb}-\mathrm{S}$, whereas in the sickle-cell trait $\mathrm{Hb}-\mathrm{A}$ and $\mathrm{Hb}-\mathrm{S}$ occurred together in the approximate proportion 60:40. Greater activity of the allele controlling $\mathrm{Hb}-\mathrm{A}$ synthesis over that for $\mathrm{Hb}-\mathrm{S}$ synthesis was thought to explain the preponderance of the former. Wells and Itano (1951) carried out further analyses in the Tiselius apparatus and confirmed that in the sickle-cell trait the mean proportion of $\mathrm{Hb}-\mathrm{S}$ was $37.5 \%$, though the range in 42 individuals was from 24 to $45 \%$. The amount for any individual fluctuated only very slightly with time. Some patients with sickle-cell anaemia who had remained sufficiently well to dispense with the need for blood trans- 
fusions over long periods were examined also. These individuals had 5 to $20 \%$ of apparently normal haemoglobin in addition to $\mathrm{Hb}-\mathrm{S}$. Under the conditions of analysis employed $\mathrm{Hb}-\mathrm{S}$ and $\mathrm{Hb}-\mathrm{F}$ would not have been distinguished, and subsequent work has established that foetal haemoglobin may accompany $\mathrm{Hb}-\mathrm{S}$ in sickle-cell anaemia under various conditions.

\section{Paper Electrophoresis}

Spaet (1953) applied the very simple technique of Durrum (1950) to the analysis of haemoglobin mixtures and obtained useful separations of $\mathrm{Hb}$-$\mathrm{A} / \mathrm{Hb}-\mathrm{S}, \mathrm{Hb}-\mathrm{A} / \mathrm{Hb}-\mathrm{C}$, and $\mathrm{Hb}-\mathrm{S} / \mathrm{Hb}-\mathrm{C}$ mixtures in veronal buffer, $p \mathrm{H}$ 8.6. $\mathrm{Hb}-\mathrm{A}$ and $\mathrm{Hb}-\mathrm{F}$ could not be differentiated. The $\mathrm{Hb}$ zones were visualized by staining with bromphenol blue.

Smith and Conley (1953) have described the paper electrophoresis of human haemoglobins with special reference to the detection of $\mathbf{H b}-\mathrm{C}$. They have used apparatus similar to that of Kunkel and Tiselius (1951) and Slater and Kunkel (1953), and

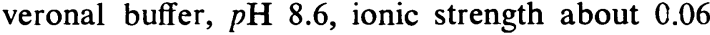
and achieve good separations of $\mathrm{Hb}-\mathrm{C}$ and $\mathrm{Hb}-\mathrm{S}$ from $\mathbf{H b}-\mathrm{A}$ in four hours' running or less, the mobilities decreasing in the order given. With running times extended to six hours they also claim a separation of $\mathrm{Hb}-\mathrm{A}$ and $\mathrm{Hb}-\mathrm{F}$, but this is apparent in their diagrams only to the extent of an enlargement of the $\mathrm{Hb}-\mathrm{A}$ spot by the slightly slower running $\mathrm{Hb}-\mathrm{F}$; the two types of $\mathrm{Hb}$ do not give resolved spots (cf. Reynaud, 1953). Schneider (1953) has also used paper electrophoresis successfully for distinguishing between normal, sickle-cell and $\mathrm{C}$ haemoglobins, using veronal buffer at $p \mathrm{H} 8.6$ to 9 .

\section{The Solubility of Sickle-cell Haemoglobin}

Sickled cells are birefringent (Sherman, 1940), suggesting orderly molecular arrangement of their contents. Perutz and Mitchison (1950) were impressed by the similarities between the optical properties in polarized light of sickled red cells and of small crystalline plates and needles of normal reduced haemoglobin. Such features as pleochroism, extinction directions, anomalous colours on compensation, and dispersion of the birefringence in the neighbourhood of absorption bands all corresponded. They then showed that although the solubilities in strong phosphate buffers were similar for the $\mathrm{HbO}_{2}$ compounds of normal and sickle-cell haemoglobins, the reduced haemoglobins differed completely. Normal reduced haemoglobin has about the solubility of $\mathrm{HbO}_{2}$, but the fall in solubility of reduced $\mathrm{Hb}-\mathrm{S}$ is very profound, the solubility being only about one hundredth of the oxy-compound under equivalent conditions. Perutz et al. (1951) later confirmed this work, using crystallized preparations of $\mathrm{Hb}-\mathrm{A}$ and $\mathrm{Hb}-\mathrm{S}$, and also showed that the same distinction in the solubilities of the reduced proteins obtained in solutions of physiological sait concentration as well as in strong buffers.

Determination of the solubility of the reduced haemoglobin in phosphate buffers of high ionic strength provides valuable means for detecting $\mathrm{Hb}-\mathrm{S}$ alone or in mixtures. The net solubility of the reduced haemoglobin for sickle-cell trait red cells is intermediate between that for $\mathrm{Hb}-\mathrm{A}$ and for pure $\mathrm{Hb}-\mathrm{S}$, and similar results are obtained when $\mathrm{Hb}-\mathrm{S}$ occurs in conjunction with appreciable amounts of other abnormal haemoglobins ( $\mathrm{Hb}-\mathrm{F}, \mathrm{C}$ or D) (Itano, 1953a and c; Beaven and White, 1953). However, where mixtures occur, the features determining solubility are complex, and the procedure needs to be used with care. In sicklecell trait, the results of Itano (1953a and c), using a system containing $1 \% \mathrm{w} / \mathrm{v}$ of haemoglobin, ale similar to those of Beaven and White (1953) at comparable ionic strength $(r / 2=4.75)$, using a system with 0.4 to $1 \% \mathrm{w} / \mathrm{v}$ of haemoglobin. But Dr. N. A. Barnicot (1954) has pointed out to us that large deviations occur on varying the amount of haemoglobin, net solubility rising with increase in added protein. Obviously, the degree of interaction in mixtures will be of great importance in determining the result. In Fig. 2, the results of solubility studies on reduced haemoglobins are given as regression lines, fitted to the experimental values at various ionic strengths for normal and non-sickling haemoglobin samples, and for sicklecell trait and sickle-cell anaemia samples.

Vandepitte and Louis (1953) have described filamentous processes derived from sickled cells, occurring in wet-preparations of aspirated marrow from sickle-cell anaemia patients, but not from the trait. These processes are presumably tactoids derived from cells which sickle at the reduced oxygen tension of the marrow sinusoids, and become trapped.

\section{Gel-formation by Reduced $\mathbf{H b}-\mathrm{S}$}

Information of a different character about the state of reduced haemoglobin in the sickled red cell was obtained by Harris (1950), who found that stroma-free, concentrated solutions of $\mathrm{Hb}-\mathrm{S}$ became very viscous on exposure to low oxygen tensions, and that under the phase-contrast microscope tactoids resembling sickled cells were visible. Tactoids are elongated bodies formed by various molecules capable of aggregation or polymerization, in solution, and, although not as organized 


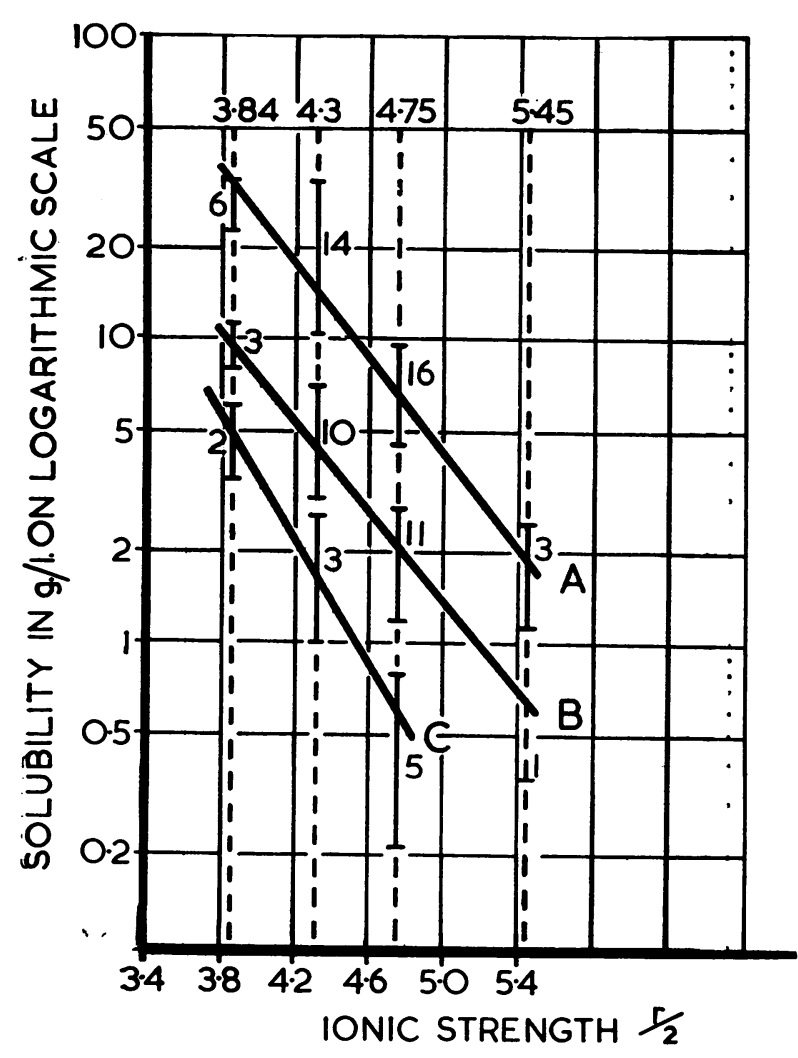

FIG. 2.-Solubility of reduced haemoglobin in pH 6.7 phosphate buffer at high ionic strengths. Regression lines are fitted to experimental values for normal and non-sickling (A), sickle-cell trait (B), and sickle-cell anaemia (C) groups. The range of values for each group, at the various ionic strengths of buffer employed, is shown in the vertical bars, and the number of observations is indicated for each.

as a crystal, possess sufficient molecular orientation to confer birefringence in polarized light (Zocher, 1925). Harris (1950) concluded that the sickling phenomenon was the result of tactoid formation. Whether the sickled cell is to be regarded as containing crystals or tactoids of reduced haemoglobin is not settled, but recent observations on the gelling of sickle-trait haemoglobin is of considerable interest in this connexion.

Singer and Chernoff (1952) found that highly concentrated solutions of sickle-trait haemoglobin gelled on long exposure to $\mathrm{CO}_{2}$ in the absence of oxygen. The gelling affected the entire solution, and tactoids were not visible. The proportion of $\mathrm{Hb}-\mathrm{S}$ was relatively low, and it was thought the interaction with the $\mathrm{Hb}-\mathrm{A}$ must occur for gel formation. Singer and Singer (1953) find that gelling of reduced haemoglobin is entirely indicative of the presence of $\mathrm{Hb}-\mathrm{S}$. The concomitant presence of normal adult haemoglobin or of $\mathrm{Hb}-\mathrm{C}$ lowers the amount of $\mathrm{Hb}-\mathrm{S}$ necessary for the phenomenon, and interaction between the molecules to form polymeric gels. On the other hand, foetal haemoglobin has no such effect in promoting gel-formation. The "lowest gelling point," expressed as the minimal concentration of total pigment at which gelling can be elicited, is lowest for sickle-cell anaemia haemoglobin, highest for sickle-cell trait haemoglobin and intermediate for sickle-Hb $\mathrm{C}$ disease, thus providing a means of distinguishing between these conditions (Singer and Singer, 1953).

\section{Other Characteristics of Sickle-cell Haemoglobin}

Perutz et al. (1951) found that $\mathrm{Hb}-\mathrm{A}$ and $\mathrm{Hb}-\mathrm{S}$ were identical in the $x$-ray crystallographic properties of their derivatives, but with one exception. A unique form of orthorhombic $\mathrm{HbO}_{2}$ was obtained from sickle-cell haemoglobin with a very large unit cell, in which the eight molecules were probably associated as dimers (Drabkin, 1951).

Amino-acid Composition.-Schroeder, Kay, and Wells (1950) analysed the globins of normal and sickle-cell anaemic negroes by fractionation of the hydrolysis products on starch partition-fractionation columns, in which approximately $98 \%$ of the total weight and $\mathrm{N}$ of the proteins were accounted for. The two globins were found not to differ with respect to their contents of basic and acidic amino-acids; the $\mathrm{Hb}-\mathrm{S}$ globin probably contained slightly less leucine and more serine and possibly less valine and more threonine. These differences cannot directly contribute to the net charges on the proteins and therefore influence their electrophoretic properties (which differ significantly, cf. Table 2), though Schroeder et al. suggest that they may affect the folding or coiling of the polypeptide chains and hence alter indirectly the disposition of charged groups in the proteins. Dickman and Moncrief (1951) found 26 primary amide groups per molecule in both $\mathrm{Hb}-\mathrm{A}$ and $\mathrm{Hb}-\mathrm{S}$.

Havinga (1953) compared the globins of normal adult human and sickle-cell anaemia haemoglobins and found them to be essentially identical with respect to optical rotary power and terminal aminoacid residues (four valine residues/mole for both $\mathrm{Hb}-\mathrm{A}$ and $\mathrm{Hb}-\mathrm{S})$. The splitting of the $\mathrm{HbCO}$ derivatives into haem and globin by treatment with acid acetone (Anson and Mirsky, 1930) was more difficult with $\mathrm{Hb}-\mathrm{S}$ than with $\mathrm{Hb}-\mathrm{A}$, suggesting a 
difference between the two globins with respect to the haem-globin linkage, as postulated earlier by Pauling et al. (1949). Havinga also obtained an indication that $\mathrm{Hb}-\mathrm{S}$ might contain a methionine end-group.

TABLE II

SOME PROPERTIES OF HUMAN HAEMOGLOBIN VARIANTS

\begin{tabular}{|c|c|c|c|}
\hline $\begin{array}{l}\text { Haemoglobin } \\
\text { Type }\end{array}$ & $\begin{array}{c}\text { Iso-electric } \\
\text { Point } \\
\text { (Itano, } \\
\text { 1953a) }\end{array}$ & $\begin{array}{c}\text { Anodic Mobi- } \\
\text { lity Relative } \\
\text { to HbA by } \\
\text { Paper Electro- } \\
\text { phoresis at } \\
\text { pH } 8.6\end{array}$ & $\begin{array}{c}\text { Solubility of Reduced } \\
\text { Haemoglobin }\end{array}$ \\
\hline Normal, A .. & $\begin{array}{c}6.87 \\
\text { (6.9 estim- } \\
\text { ated from } \\
\text { Zinsser, } \\
(1952)\end{array}$ & - & $\begin{array}{l}\text { High } \\
\text { M 6.8g. 1.; } 4 \cdot 45-9 \cdot 3, \mathrm{r} / 2 \\
4.75 \text { (Beaven and } \\
\text { White, 1953). } \\
1.12-2 \cdot 48 \text { (Beaven and } \\
\text { White, 1953); } 1 \cdot 39 \pm \\
0.15 \text { (Itano, 1953c). } \mathrm{r} / 2 \\
5.45\end{array}$ \\
\hline Foetal, F & $\begin{array}{c}6.98 \\
\text { (Estimated } \\
\text { from } \\
\text { Zinsser, } \\
1952 \text { ) }\end{array}$ & Slightly less & Higher than $\mathbf{A}$ \\
\hline Sickle-cell, S. & 7.09 & Less & $\begin{array}{l}\text { Very low } \\
\text { M0.66g. 1. } 0.21-0.78, \\
\text { r/2 4.75 (Beaven and } \\
\text { White, 1953) } \\
0.1-0.95, \quad \text { r } 2 \\
\text { (Itano, 1953c). }\end{array}$ \\
\hline $\begin{array}{l}\text { Haemoglobin C } \\
\text { Haemoglobin D }\end{array}$ & 7.09 & $\begin{array}{c}\text { Less than } S \\
\text { and } D \\
\text { Less } \\
\text { Same as HbS }\end{array}$ & $\begin{array}{l}\text { High } \\
\text { High }\end{array}$ \\
\hline $\begin{array}{c}\text { Haemoglobin } \mathrm{E} \\
\text { (Itano, et al., } \\
1954)\end{array}$ & & $\begin{array}{l}\text { Between A } \\
\text { and S by free } \\
\text { Electrophore- } \\
\text { sis (Itano et } \\
\text { al., 1954). }\end{array}$ & $\begin{array}{c}\text { High } \\
\text { (Itano et al., 1954). }\end{array}$ \\
\hline
\end{tabular}

Sulphydryl Groups in Hb-S.-Ingbar and Kass (1951), following up an indication that chemical inhibitors of the sickling process were also known $\mathrm{SH}$ group inhibitors, determined the SH-group content of normal adult, sickle-cell anaemia and sickle-cell trait haemoglobins by amperometric titration in $0.85 \%$ saline with $0.001 \mathrm{~N}$ silver nitrate. They found $2.04 \pm 0.04 \mathrm{SH}$ group per mole $(68,000)$ in normal adult haemoglobin in agreement with Hughes (1949) and $3.07 \pm .16$ groups per mole in sickle cell anaemia haemoglobin. The two sickle-cell trait bloods studied gave an intermediate value, $2.46 \pm 0.03$, equivalent to about $46 \% \mathrm{Hb}-\mathrm{S}$ in admixture with $\mathrm{Hb}-\mathbf{A}$. Ingbar and Kass pointed out that their results did not distinguish between a difference in total SH group content or a difference in reactivity of the $\mathrm{SH}$ groups of $\mathrm{Hb}-\mathrm{A}$ and $\mathrm{Hb}-\mathrm{S}$; they found, however, that the SH groups of both types of $\mathrm{Hb}$ were blocked stoichiometrically by p-chloromercuribenzoate.
Resistance of Sickle Cells to Heinz Body Formation.-Fisher (1953a) reported the formation of Heinz bodies in non-sickling adult and infant erythrocytes by exposure to $2 \%$ aqueous bisulphite (metabisulphite) but not in sickle-cell anaemia or sickle-cell trait erythrocytes under the same conditions, and suggested that the presumptive denaturation of globin associated with Heinz body formation involved reactive groups (possibly $-\mathrm{SH}$ ) which were not available to the above reagent in $\mathrm{Hb}-\mathrm{S}$; this suggestion is consistent with the differences in polypeptide chain configuration between $\mathrm{Hb}-\mathrm{A}$ and $\mathrm{Hb}-\mathrm{S}$ envisaged by Havinga and Itano (1953). Normal haemoglobin readily enters into a complex oxidation-reduction reaction with phenylhydrazine (Beavan and White, 1954) but our preliminary observations suggest that $\mathrm{Hb}-\mathrm{S}$ is much less active in this respect also than is $\mathbf{H b}-\mathbf{A}$.

\section{Foetal Haemoglobin in Sickle-cell Anaemia}

Using alkali-denaturation techniques, Singer $e t$ al. (1951a) found that $2-24 \%$ of resistant haemoglobin frequently occurred in the erythrocytes of sicklecell anaemia but not in the trait. Combining this test with that of tactoid formation for sickle-cell haemoglobin, Singer and Chernoff (1952) recognized normal adult $\mathrm{Hb}-\mathrm{A}$ and sickle-cell $\mathrm{Hb}-\mathrm{S}$ in the trait cells, and showed that in sickle-cell anaemia the haemoglobin $S$ might be accompanied by alkali-resistant, foetal-type $\mathrm{Hb}-\mathrm{F}$ (Fig. 1).

The presence of foetal haemoglobin in sickle-cell anaemia has also been established by Itano (1953a and $b$ ) by the alkali-denaturation and spectrophotometric methods, and by solubility measurements. The presence of foetal haemoglobin in the sicklecell increases the net solubility (Itano, 1953a, b, c) which is advantageous to the individual. There is also some evidence that sickling is difficult to elicit in the young infants of sicklaemic parents, possibly due to a persistence of foetal haemoglobin (Watson, 1948). In this connexion the failure of $\mathrm{Hb}-\mathrm{F}$ to enhance the gelling power of the $\mathrm{Hb}-\mathrm{S}$ by interaction is of interest (Singer and Singer, 1953).

Singer and Fisher (1952) have followed survival of transfused sickle-cell anaemia red cells containing $12-18 \%$ of $\mathrm{Hb}-\mathrm{F}$. Evidence was obtained that $\mathrm{Hb}-\mathrm{F}$ persisted longer than $\mathrm{Hb}-\mathrm{S}$ in the circulation of recipients, and that sickle-cell anaemia patients may have three classes of red cells containing (a) $\mathrm{Hb}-\mathrm{S}$ only, $(b)$ a mixture of $\mathrm{Hb}-\mathrm{S}$ and $\mathrm{Hb}-\mathrm{F}$ and (c) cells mainly of $\mathrm{Hb}-\mathrm{F}$. The life span of the three classes is considerably shortened in $(a)$, intermediate in (b), and longest in (c). Singer and Fisher (1953a) suggested that for practical purposes 
the proportion of $\mathrm{Hb}-\mathrm{S}$ in sickle-cell anaemia blood might be expressed as $100 \%$ less the proportion of $\mathrm{Hb}-\mathrm{F}$ found by alkali denaturation. In two cases at least, however, they found evidence for 10-20\% $\mathrm{Hb}-\mathrm{A}$ accompanying about $10 \% \mathrm{Hb}-\mathrm{F}$.

\section{The Genetics of Sickle-cell Anaemia}

Neel $(1951,1952)$ has postulated that the sickling phenomenon is due to a gene, which in single dose produces the trait, and in double dose, the homozygous state with development of sickle-cell anaemia. This is well supported by the chemical evidence for a mixture of sickle-cell $\mathrm{Hb}$ and slight excess of normal $\mathrm{Hb}$ in the trait cells, but an excess of sickle-Hb with perhaps some foetal $\mathrm{Hb}$, in the anaemia. The theory requires that both parents should carry the gene, and their blood sickle. This is largely true, but exceptions occur. Singer and Fisher (1953b) have shown that in some anomalous cases the erythrocytes of the non-sickling parent may contain no more than $5 \%$ of sickle-cell $\mathrm{Hb}$ detectable only by careful electrophoretic analysis. The investigations of Singer and Singer (1953) also suggest that gelling may not occur where sickle-cell trait haemoglobin contains less than about $20 \%$ of $\mathrm{Hb}-\mathrm{S}$, and that under these circumstances failure of the red cells to sickle under test conditions may be expected.

In some cases it appears that one parent has the sickle trait, the other the thalassaemia trait (Cooley or Mediterranean trait), and that although the genes for the two conditions are separate, they may interact to produce a haemolytic syndrome with features of both sickle and Mediterranean anaemias in some of the offspring (Powell, Rodarte, and Neel, 1950; Sturgeon, Itano, and Valentine, 1952). This condition was first described in Sicilian and southern Italian families by Silvestroni and Bianco (1952) and called micro-drepanocytic disease. The interaction of the gene for $\mathrm{Hb}-\mathrm{S}$ with those for two further haemoglobins (C and D) leads to a further proportion of apparently anomalous cases of sickle-cell anaemia (vide infra).

Since sickle-cell anaemia is a serious disease with a high mortality rate, it might be expected that the gene would be gradually eliminated. This does not appear to be so, and there is some evidence that a high proportion of persons with sickle-cell trait may be maintained in various African populations by virtue of their greater resistance to parasitic infection (Raper, 1949), particularly to malarial infection (Brain, 1952; Beet, 1946; Allison, 1954). Allison's data for Luo tribesmen in East Africa indicates that possession of the sickle-cell trait is prosective against Plasmodium falciparum infec- tion in particular. Allison (1954) and Lehmann (1953) suggest further that the high proportion of foetal haemoglobin in young infants' cells is responsible for their relative resistance to malarial parasitization compared with older children in whom normal $\mathrm{Hb}-\mathrm{A}$ has replaced $\mathrm{Hb}-\mathrm{F}$.

\section{HAEMOGLOBINS IN HAEMOLYTIC ANAEMIA DUE TO SICKLE-CELL : THALASSAEMIA INTERACTION}

Among families of central and southern Italian and Sicilian stock, Silvestroni and Bianco recognized examples of the thalassaemia syndromes, and of sickle-cell trait and anaemia. They also described a condition which appeared to share genetic characters of both groups, which they called microdrepanocytic disease, and which appeared in families where one parent carried the sickle-cell trait and the other the Mediterranean trait (see Silvestroni and Bianco, 1952). A similar condition has been described in America, chiefly among families of Mediterranean origin (Powell et al. 1950; Sturgeon et al. 1952; Neel, Itano, and Lawrence, 1953) and in Greece (Caminopetros, 1952).

In thalassaemia, genetic interference with the svnthesis of normal adult haemoglobin may occur (Rich, 1952), the extent of interference being much greater in the homozvgous thalassaemia major than in the heterozygous minor condition; the $\mathrm{Hb}-\mathrm{F}$ which is present to a variable extent may be regarded as compensatory. In sickle cell-thalassaemia disease genes for both diseases are present, possibly in a doubly heterozygous condition (Silvestroni and Bianco, 1952). Hb-S is synthesized in considerable excess (Sturgeon et al., 1952), and $\mathrm{Hb}-\mathrm{A}$ and $\mathrm{Hb}-\mathrm{F}$ may be present in addition (Itano, 1953b).

The reviewers have observed $20 \%$ of $\mathrm{Hb}-\mathrm{F}$ and $80 \% \mathrm{Hb}-\mathrm{S}$ in the red cells of an Arab woman with this condition. (This sample was kindly made available by Dr. N. A. F. Young from Kuwait.) The condition has been observed in this country in a child, whose father is of West African descent and has sickle-cell trait, and whose mother is from Naples and has Mediterranean trait (Humble, Anderson, White and Freeman, 1954). The patient's haemoglobin appears to be predominantly $\mathrm{Hb}-\mathrm{S}$, and $\mathrm{Hb}-\mathrm{F}$ has not been found.

Ascenzie and Silvestroni (1953) have shown that the high content of $\mathrm{Hb}-\mathrm{S}$ in microdrepanocytic disease is associated with birefringence of the sickled red cells, and with the formation of birefringent tactoids in rediced concentrated solutions of the haemoglobin. 


\section{HAEMOGLOBIN C}

Haemoglobin $\mathrm{C}$ and $\mathrm{D}$ are two further abnormal haemoglobins that have been well characterized, and are of importance since they occur particularly in the negro races, and genetic interaction with sickle-cell occurs, resulting in haemolytic anaemias of moderate degree.

The first of the haemoglobins, now called haemoglobin C, was described as haemoglobin III by Itano and Neel (1950) and Kaplan, Zuelzer, and Neel (1951). In certain negro families, children were found to suffer from a rather mild haemolytic disorder, with sickling of the red cells on reduction. Free electrophoretic analysis revealed that the haemoglobin of these children comprised a mixture of $\mathrm{Hb}-\mathrm{S}$ and the hitherto unrecognized pigment with greater mobility than either $\mathrm{Hb}-\mathrm{A}$ or $\mathrm{Hb}-\mathrm{S}$. In each case, one parent carried sickle-cell trait, and the other possessed trait characteristics for the new haemoglobin, their red cells containing $\mathrm{Hb}-\mathrm{A}$ and $\mathrm{Hb}-\mathrm{C}$.

Numerous examples of the haemoglobin-C trait and of haemoglobin $\mathrm{C}$-sickle disease have now been studied (Kaplan et al. 1953; Lehmann and Edington, 1954). The trait condition appears harmless, though small numbers of target cells and slightly hypochromatic red cells may be present in the blood (Ranney, Larson, and McCormack, 1953), and Smith and Conley (1953) found an incidence of $2 \%$ among 500 American negroes, whereas $\mathrm{Hb}-\mathrm{S}$ was encountered in $8.4 \%$. Larson and Ranney (1953) found $56 \%$ of $\mathrm{Hb}-\mathrm{A}$ and $44 \%$ of $\mathrm{Hb}-\mathrm{C}$ in the trait. The homozygous condition, with predominance of haemoglobin $\mathrm{C}$, has been described by Ranney et al. (1953), Spaet, Alway, and Ward (1953), and Levin, Schneider, Cudd, and Johnson (1953). Although not associated with clinical anaemia, the homozygous individuals exhibit slight reticulocytosis and numerous target cells in the blood, decreased fragility and absence of sickling, and splenomegaly.

Among the offspring of parents with sickle-trait and haemoglobin $C$ trait, individuals appear with a mixture of $\mathrm{Hb}-\mathrm{S}$ and $\mathrm{Hb}-\mathrm{C}$; the two haemoglobins appear to be rather evenly balanced in amount, and Larson and Ranney (1953) give $48 \%$ $\mathrm{Hb}-\mathrm{S}$ and $52 \% \mathrm{Hb}-\mathrm{C}$. These individuals often have a definite haemolytic process of mild degree. with moderate reticulocytosis and bilirubinaemia, and numerous target cells in the blood smear. There is a distinct tendency to increased haemolysis during pregnancy, and vascular lesions occur (Smith and Conley, 1953). In their studies of offspring from matings of sickle trait $\times \mathrm{Hb}-\mathrm{C}$ trait, Neel, Kaplan, and Zuelzer (1953) found the ratios for $\mathrm{Hb}-\mathrm{C}$ trait : sickle-cell trait: normal : haemoglobin-C-sickle cell disease to be $4: 1: 5: 2$.

In a study of various physico-chemical properties of apparently homogenous haemoglobin C, Ranney et al. (1953) found the only distinction from $\mathrm{Hb}-\mathrm{A}$ to lie in the difference of electrophoretic mobility. Since there is a considerable difference in mobility between $\mathrm{Hb}-\mathrm{A}$ and $\mathrm{Hb}-\mathrm{C}$, and $\mathrm{Hb}-\mathrm{S}$ is intermediate in behaviour, paper electrophoresis is particularly suitable for demonstrating this group (Spaet, 1953; Smith and Con!ey, 1953). In Fig. 3 Hb-S and $\mathrm{Hb}-\mathrm{C}$ are demonstrated in the blood of a Jamaican woman resident in this country.

Itano (1953c) has studied the solubility of the reduced haemoglobin, and found it higher than normal in one homozygous specimen and eight trait samples, whilst considerable lowering of solubility was found in cases of haemoglobin C-sickle-cell disease. intermediate between values for sickle-trait and pure sickle-cell haemoglobin.

\section{HAEMOGLOBIN D}

In 1934 Cooke and Mack described a family apparently of white American ancestry, in which the father and two young children all exhibited slow sickling of the red cells on reduction. The children both had haemolytic anaemia, and an enlarged spleen was removed from the younger without effect.

In 1951, Itano re-examined the mother and two affected offspring, confirming that the red cells of the latter could sickle. On free electrophoresis of the haemoglobins, the offspring yielded uniform components with the mobility of $\mathrm{Hb}-\mathrm{S}$, and the solubility of the reduced haemoglobin was considerably lowered, approaching that of $\mathrm{Hb}-\mathrm{S}$. The red cells of the mother, and of a non-anaemic brother and sister, could not be sickled, but on free electrophoresis separation occurred into two components, resembling the $\mathrm{Hb}-\mathrm{A}$ and $\mathrm{Hb}-\mathrm{S}$ fractions of sicklecell trait blood. However, the solubility of the reduced haemoglobin in these three individuals was close to normal, not lowered as in sickle-cell trait.

Itano (1951) called this new haemoglobin, with electrophoretic mobility resembling $\mathrm{Hb}-\mathrm{S}$ but normal solubility when reduced, haemoglobin $\mathbf{D}$. He considered that it occurred in the heterozygous trait condition in the mother, and was similarly inherited in the two unaffected offspring. In the two affected offspring, however, genes for synthesis of $\mathrm{Hb}-\mathrm{S}$ and $\mathrm{Hb}-\mathrm{D}$ were inherited from father and mother respectively. Further work (Itano, 1953c) has confirmed the solubility properties in $\mathrm{Hb}-\mathrm{D}$ trait and $\mathrm{Hb}-\mathrm{D}-\mathrm{Hb}-\mathrm{S}$ disease, and in the latter condition Itano (1953a) has also detected $\mathrm{Hb}-\mathrm{F}$. 


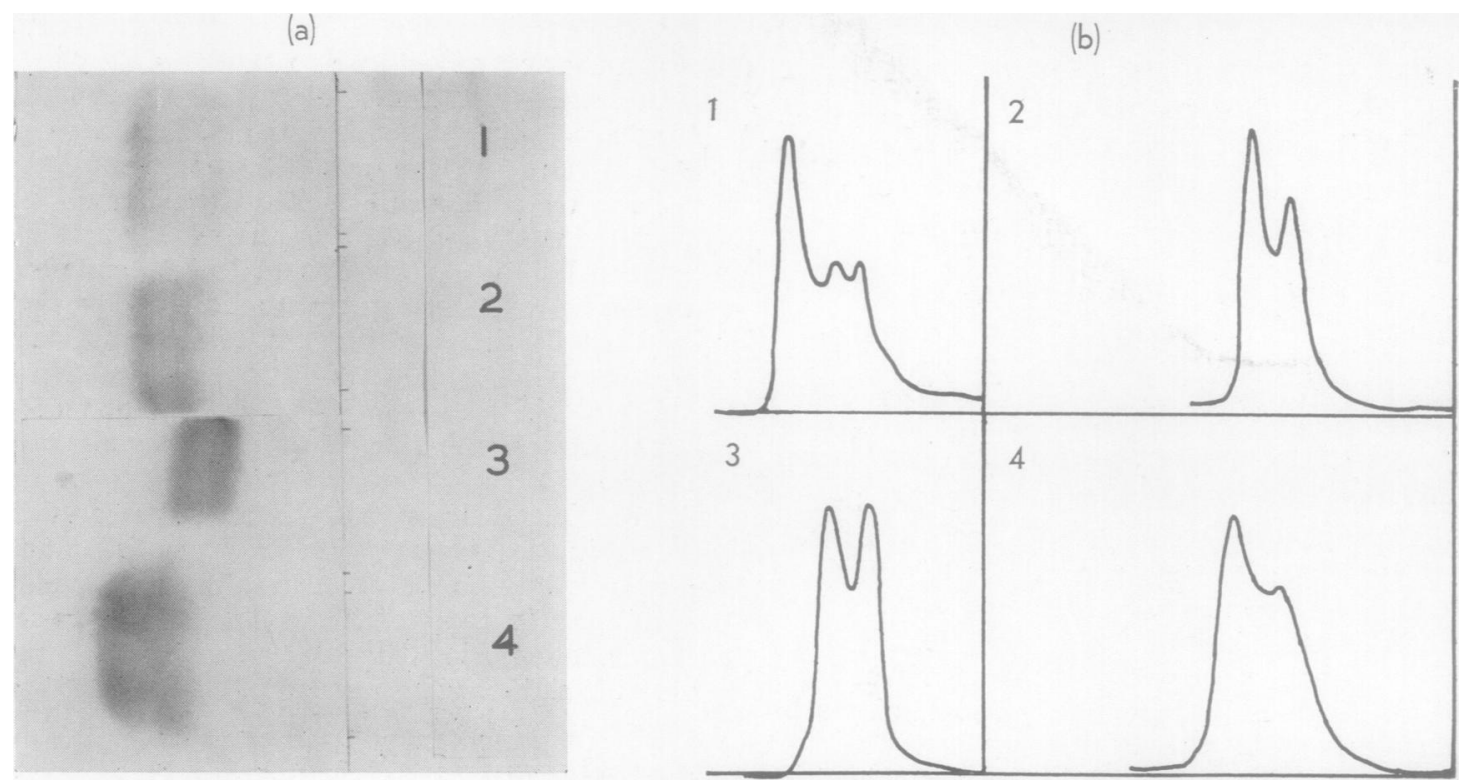

FIG. 3.-Paper electrophoresis of human haemoglobins run as $\mathrm{HbCO}$ on Whatman No. 1 paper strips $24 \times 9 \mathrm{~cm}$., $p \mathrm{H} 8.6$, barbitone buffer r 20.05 . $210 \mathrm{v}$. applied at 5 ma. for 18 hours. (a) Strips photographed unstained; $(b)$ tracings of strips after staining with naphthalene black and scanning by automatically recording densitometer (Lawrence, 1954). 1 shows normal haemoglobin mixed wi.h haemoglobins from sickle cell-haemoglobin $\mathrm{C}$ disease. Order of peaks, left to right, normal, sickle-cell, and C haemoglobins. 2 shows haemoglobin D trait: normal and D haemoglobins. 3 shows sickle-cell-haemoglobin C disease. 4 shows sickle-cell trait with normal and sickle-cell haemoglobins. The mobility of sickle-cell and D haemoglobin is similar.

Itano (1951) considers that $\mathrm{Hb}-\mathrm{S}$ and $\mathrm{Hb}-\mathrm{D}$ interact on reduction, with lowering of the net solubility which may be greater in degree that that for simple sickle-cell trait; this may account for the ready destruction of the cells in the patients' circulation.

On paper electrophoresis, the similarity in behaviour between $\mathrm{Hb}-\mathrm{S}$ and $\mathrm{Hb}-\mathrm{D}$ is maintained. In Fig. 3, paper electrophoretic analysis is illustrated for a European woman carrying $\mathrm{Hb}-\mathrm{D}$ trait, together with the analysis of her husband, carrying sickle-cell trait. The solubilities of the reduced haemoglobins are respectively normal and lowered to the extent found in sickle-cell trait. One child in the family has haemolytic anaemia, and paper electrophoresis reveals a large component resembling $\mathrm{Hb}-\mathrm{S}$ while the solubility on reduction is within the range found in sickle-cell trait.

\section{HAEMOGLOBIN E}

Itano, Bergren, and Sturgeon (1954) have recently reported the binding of a fourth abnormal haemoglobin $(\mathrm{Hb}-\mathrm{E})$ in the red cells of a child with an atypical anaemia. The electrophoretic mobility of $\mathrm{Hb}-\mathrm{E}$ was greater than that of $\mathrm{Hb}-\mathrm{A}$ but slightly less than that of $\mathrm{Hb}-\mathrm{S}$. The ultra-violet absorption spectrum, solubility, and alkali-denaturation characteristics were similar to those of $\mathbf{H b}-\mathbf{A}$. The other constituent of the haemoglobin from this patient was identified as $\mathrm{Hb}-\mathrm{F}$, and formed $41 \%$ of the total.

\section{CONCLUSION}

Striking progress has been made in recent years in the study of the biochemical defects underlying hereditary anaemias of the sickle-cell, thalassaemia, and related and inter-connected groups. A series of abnormal human haemoglobins is now firmly recognized, in addition to normal adult and foetal forms. Information on their genetic, haematological, and clinical implications is rapidly being assembled. The methods used in characterization of these haemoglobins are based on the fundamental physico-chemical procedures of protein chemistry. Some of these methods must remain as specialized techniques, but others, such as paper electrophoresis and photocolorimetric determination of alkali-denaturation rates, can be easily applied in the clinical laboratory.

Apart from the recognition of abnormal derivatives of chemically modified normal haemoglobins by spectroscopic procedures and investigation of pyrrol pigment metabolism, the variants of haemoglobin should be searched for in any obscure haemolytic anaemia in which diagnosis is not established by the conventional haematological procedures and on clinical grounds. This is particularly so where sickling of the red cells can be elicited, or the bloods film presents features such as numerous target cells. 
REFERENCES

Adair, G. S. (1924). Proc. Camb. phil. Soc. biol. Sci., 1, 75. (1925a). Proc roy. Soc. A, 108, 627.

(1925b). Ibid., 109292

Allison, A. C. (1954). Brit. med. J., 1, 290.

Andersch. M. A., Wilson, D. A., and Menten, M. L. (1944). J. biol. Chem., 153, 301 .

Anson, M. L., and Mirsky, A. E. (1925). J. Physiol., Lond., 60, 50, $161,221$.

- (1930). J. gen. Physiol., 13, 469.

Antweiler, H. J. (1949). Kolloidzschr., 115, 130.

(1952). In Die Quantitative Elektrophorese in der Medizin, ed. Antweiler, H. J. Springer: Berlin, Göttingen and Heidelberg.

Ascenzi, A., and Silvestroni, E. (1953). Blood, 8, 1061.

Baar, H. S., and Hickmans, E. M. (1941-2). J. Physiol., Lond., 100, 3P. - and Lloyd, T. W. (1943). Arch. Dis. Childh., 18, 124.

Baikie, G and Valtis D. J (1954). Brit med. J.' 73.

Barcroft, J. (1928). In The Respiratory Function of the Blood, Pt. 2, Haemoglobin. University Press, Cambridge.

(1934). Features in the Architecture of Physiological Function. University Press, Cambridge.

- (1946). Researches on Pre-Natal Life, Vol. 1. Blackwell, Oxford. Barcroft Memorial Volume (1949). Haemoglobin. Ed. F. J. W. Roughton and J. C. Kendrew. Butterworth, London.

Barcroft, H., Gibson, Q. H., and Harrison, D. C. (1949). In Barcroft Memorial Volume; Haemoglobin, p. 223. Fd. F. J. W. Roughton and J. C. Kendrew. Butterworth, London.

Barnicot, N. A. (1954). Personal communication.

Beaven, G. H., Hoch, H., and Holiday, E. R. (1951). Biochem. J., 49, 374. - and White, J. C. (1953), Nature, Lond., 172, 1006.

- - (1954). Ibid., 173, 389.

Beet, E. A. (1946). E. Afr. med. J., 23, 75.

Bernhart, F. W., and Skeggs, L. (1943). J. biol. Chem. (vol. 322), 147,19

Betke, K. (1951). Biochem. Z., 322, 186 (1953). Naturwissenschaften, 40, 60.

Bianco, I. (1948). Policlinico, Sez, prat., 55, 103.

Bock, A. V., Field, H., Jr., and Adair, G. S. (1924). J. biol. Chem.,

Bohr, C., Hasselbalch, K., and Krogh, A. (1904). Skand. Arch. Physiol., 16, 402.

Bragg, W. L'. (1952). Proc. phys. Soc., Lond., B., 65, 833. (1953). In Les Protéines, p. 100. Institut International de Chimie Solvay. Neuvième Conseil de Chimie. Stoops, Brussels. Howells, E. R., and Perutz, M. F. (1952). Acta cryst., 5, 136. and Perutz, M. F. (1952a). Ibid., 5, 277, 323

(1952b). Proc. roy. Soc. A.. 213, 425

Brain, P. (1952). S. Afr. med. J. 26, 925.

Brinkman, R., and Jonxis, J. H. P. (1935). J. Physiol., Lond., 85, 117. (1936). Ibid., 88, 162.

- Wildschut, A., and Wittermans, A. (1934). Ibid., 80, 377.

Burk, N. F., and Greenberg, D. M. (1930). J. biol. Chem., 87, 197.

Caminopetros, J. (1952). Lancet, 1, 687.

Chernoff, A. I. (1953a). Blood, 8, 399.

(1953b). Ibid., 8, 413.

Chibnall, A. C. (1942), Proc. roy. Soc. B., 131, 136.

Christiansen, J., Douglas, C. G., and Haldane, J. S (1914). J. Physiol., Lond., 48, 244.

Cohn. E. J. (1925). Physiol. Rev., 5, 349.

- (1936). Chem. Rev., 19, 241.

and Edsall, J. T. (1943). Protein, Amino Acids and Peptides as Ions and Dipolar Ions. Reinhold, New York.

Comly, H. H. (1945). J. Amer. med. Ass., 129, 112.

Conant, J. B. (1933). Harvey Lect., 28, 159.

Cooke, J. V., and Mack, J. K. (1934). J. Pediat., 5, 601.

Cooley, T. B., and Lee, P. (1925). Trans. Amer. pediat. Soc., 37, 29.

Cornblath, M., and Hartmann, A. F. (1948). J. Pediat., 33, 421.

Cremer, H. D., and Tiselitus, A. (1950). Biochem. Z., 320, 273.

Crick, F. H. C.' (1952). Acta cryst., 5, 381 .

Dacie J. V., Mollison, P. L., Richardson, N., Selwyn, J. G., and Shapiro, L. (1953). Quart. J. Med., n.s., $22,79$.

Darling, R. C., and Roughton, F. J. W. (1942). Amer. J. Physiol., 137, 56.

Smith, C. A., Asmussen, F., and Cohen, F. M. (1941). J. clin. Invest., $20,739$.

Darrow, R. R., Nowakovsky, S., and Austin, M. H. (1940) Arch. Path., Chicago, 30, 873 .

Debye, P.' (1923). Phys Z., 24, 334.

- and Huckel, E (1923).'Ibid $24,185,305$.

Dickman, S. R., and Moncrief, I. H. (1951). Proc. Soc. exp. Biol. N.Y., 77, 631 . Douglas, C. G., Haldane, J. S., and Haldane, J. B. S. (1912).

Drabkin, D. L. (1945). Amer. J. med. Sci., 209, 268. (1946). J. biol. Chem., 164, 703 .

- (1951). Physiol. Rev., 31, 345.

Durrum, E. L. (1950). J. Amer. chem. Soc., 72, 2943.

Eastman, N. J., Geiling, E. M. K., and De Lawder, A. M. (1933). Bull. Johns Hopk. Hosp., 53, 246.

Edsall, J. T. (1947). Advanc. Protein Chem., 3, 383

Fisher, B. (1953a). Science, 118, 631.

- (1953b). Amer. J. clin. Path., 23, 246.
Flynn, F. V., and de Mayo, P. (1951). Lancet, 2, 235.

Fox, H. Munro, Gilchrist, B. M., and Phear, E. A. (1951). Proc. roy. Soc., B., 138, 514 .

Gajdos, A. (1953). Sang, 24, 185.

Gardikas, C., Scott, D. G., and Wilkinson, J. F. (1953). Arch. Dis. Childh., 28, 38 .

Gibson, Q. H. and Harrison D. C. (1947). Lancet, 2, 941.

Gilmour, J. R. (1941). J. Path. Bact., 52, 25.

Goodman, M., and Campbell, D. H. (1953). Blood, 8, 422

Gorter, E., and Grendel, F. (1926). Trans. Farad. Soc., 22, 477.

Green, A. A. (1931). J. biol. Chem., 93, 495, 507, 517.

Cohn, E. J., and Blanchard, M. H. (1935). Ibid., 109, 631

Haldane, J. S. (1900). J. Physiol., Lond., 25, 331.

Harris, S. (1953). Lorrain (1897). Ibid., 22, 231. Eugenics Laboratory Memoirs, No. 37. Cambridge Univ. Press, London.

Harris, J. W. (1950). Proc. Soc. exp. Biol., N.Y., 75, 197.

Haselhorst, G., and Stromberger, K. (1931). Ż. Geburtsh. Gynäk., $100,48$.

Haurowitz, F. (1935). Hoppe Seyl. Z., physiol. Chem., 232, 125.

(1949). In Haemoglobin, p. 53. Ed. Roughton, F. J. W., and, Kendrew, J. C. Butterworth, London.

and Hardin, R. L. (1954). The Proteins, p. 279, Vol. 2, Pt. A Ed. Neurath, H., and Bailey, K. Academic Press, New York.

and Waelsch, H. (1929), Hoppe Seyl., $Z$. physiol. Chem., 182, 82.

Havinga, E. (1953). Proc. nat. Acad. Sci., Wash. 39, 59.

and Itano, H. A. (1953). Ibid., 39, 65.

Heidelberger, M., and Landsteiner, K. (1923). J. exp. Med., 38, 561.

Hektoen, L., and Boor, A. K. (1931). J. infect. Dis., 49, 29.

- and Schulhof, K. (1923). Ibid., 33, 224.

Hill, R. (1935). Cited by Barcroft, J. (1946). in Researches on PreNatal Life, Vol. 1, p. 163. Blackwell, Oxford.

and Holden, H. F. (1926). Biochem. J., 20, 1326.

Hoch, H. (1949). Ibid., 45, 285.

Holida (1950). Ibid., 46, 199.

oliday, E. R. (1937). J. sci. Instrum., 14, 166.

(1950). In Analytical Absorption Spectroscopy, p. 268. Ed. by

Mellon, M. G. Wiley, New York; Chapman and Hall, London

Hüfner, G. (1894). Arch. Anat. Physiol., Lpz. (Physiol. Abt.), p. 130.

Hughes, W. L., Jr. (1949). Cold. Spr. Harb. Symp. quant. Biol., 14. 79

Humble, J. G., Anderson, I., White, J. C., and Freeman, T.' (1954). Journal of Clinical Pathology, 7, 201.

Ikin, E. W., Lehmann, H., and Mourant, A. E. (1953). Brit. med. J., 2, 602 .

Ingbar, S. H., and Kass, E. H. (1951). Proc. Soc. exp. Biol. N.Y., 77, 74.

Itano, H. A. (1951). Proc. nat. Acad. Sci., Wash., 37, 775. (1953a). Science, 117, 89 .

(1953b). Fed. Proc., 12, 224.

(1953c). Arch. Biochem. Biophys., 47, 148.

76, 2278 .

Jongbloed, J. (1938). J. Physiol., Lond., 92, 229.

Jonxis, J. H. P. (1949). In Haemoglobin, p. 261. Ed. Roughton, F. J. W., and Kendrew, J. C. Butterworth, London.

Jope, E. M. (1949). In Haemoglobin, p. 205. Ed. Roughton, F. J. W. and Kendrew, J. C. Butterworth, London.

Jope, H. M., and O'Brien, J. R. P. (1949). Nature, Lond., 164, 612.

Jope, H. M., and O'Brien, J. R. P. (1949). In Haemoglobin, p. 269. Ed. Roughton, F. J. W., and Kendrew, J. C. Butterworth, London.

Kaplan, E., Zuelzer, W. W., and Neel, J. V. (1951). Blood, 6, 1240.

Karvonen, (1953). Ibid., 8, 735. (1949). In Haemoglobin, p. 279. Ed. Roughton,

Kendrew, J. C. Butterworth, London.

Keilin, D. (1953). Nature, Lond., 172, 390.

- and Hartree, E. F. (1943). Ibid.. 151, 390

and Ryley, J. F. (1953). Ibid., 172, 451. and Smith, J. D. (1947). Ibid., 159, 692.

and Tissières, A. (1953). Ibid., 172, 393.

Kendrew, J. C. (1949). Endeavour, 8, 80.

- and Perutz, M. F. (1948). Proc. roy. Soc., A., 194, 375

King, E. J., Gilchrist, M., Wootton, I. D. P., Donaldson, R., Sisson, R. B., Macfarlane, R. G., Jope, H. M., O'Brien, J. R. P., Peterson, J. M., and Strangeways, D. H. (1947). Lancet, 2, 789.

Körber, E. (1866). Inaug. Dissertation, Dorpat. Cited by Bischoff, $\mathbf{H}$. (1926). Z. ges. exp. Med., 48, 472 .

Krüger, F. von (1888). Z. Biol., $24,318$.

Kunkel, H. G., and Tiselius, A. (1951). J. gen. Physiol., 35, 89.

Künzer, W., and Savelsberg, W. (1951). Klin. Wschr., 29, 648.

Lambrechts, A., and Martin H. (1951). Bull. Soc. Chim. biol., Paris, 33,565 .

Landsteiner, K. (1945). The Specificity of Serological Reactions. revised ed. Harvard Univ. Press.

Larsen, G. (1951), Proc. 3rd. int. Cong. Int. Soc. Haematology Cambridge, 1950. Paper No. 76, p. 25. Heinemann, London.

Larson, D. L., and Ranney, H. M. (1953). J. clin. Invest., 32, 1070.

Laurence, D. J. R. (1954). J. sci. Instrum., 31, 137. 
Lecks, H. I. (1950). Amer. J. Dis. Child., 79, 117.

$\longrightarrow$ and Wolman, I. J. (1950). Amer. J. med. Sci., 219, 684

Lederer, M. (1951). Research, 4, 371.

Lehmann, H. (1953). Journal of Clincial Pathology, 6, 329.

- and Edington, G. M. (1954). Ibid., 7, 171.

Leibson, R. G., Likhnitzky, I. I., and Sax, M. G. (1936). J. Physiol., Lond. 87, 97.

I.emberg, R., and Legge, J. W. (1949). Hematin Compounds and Bile Pigments. Interscience, New York and London.

Levin, W. C., Schneider, R. G., Cudd, J. A., and Johnson, J. E. (1953). J. Lab. clin. Med., 42, 918 .

Linden, A. C.. van der (1949). Thesis Univ. Amsterdam; Maandschr. Kindergeneesk., 17, 231.

Liquori, A. M. (1951). Nature, Lond., 167, 950.

Longsworth, L. G. (1942). Chem, Rev, 30, 323.

Mann, T.. and O'Brien, D. (1951). Lancet, 1, 1233.

Marrack, J. R. (1938). "The Chemistry of Antigens and Antibodies." Spec. Rep. Ser. med. Res. Coun. Lond., No. 230

Martin, N. H., and Franglen, G. T. (1954). Journal of Clinical Pathology. $7,87$.

McCarthy E. F. (1943). J. Physiol., Lond., 102, 55.

McCutcheon, F. H. (1936). J. cell. comp. Phvsiol., 8, 63.

McDonald, H. J., Urbin, M. C., and Williamson, M.B. (1951). J. coll. Sci., 6, 236.

Moncrieff, A., and Whithy, L. E. H. (1934). Lancet, 2, 648.

Neel, J. V. (1951). Blcod, 6, 389.

- (1952). Ibid., 7, 467.

Itano, H. A., and Lawrence, J. S. (1953). Ibid., 8, 434

- Kaplan, E., and Zuelzer, W. W. (1953). Ibid, 8, 724.

Northrep, J. H., and Anson, M. L. (1929). J. gen. Physiol., 12. 543.

Ott, H., Huber, H., and Körver, G. (1952). Klin. Wschr., 30, 34.

Palmer, W. G. (1944). Valency: Classical and Modern. 'University Press, Cambridge.

Pauling L. (1935). Proc. nat. Acad. Sci., Wash., 21, 186 (1940). The Nature of the Chemical Bond, 2nd ed. Cornel Univ. Press, Ithaca, New York.

(1949). In Haemoglobin, p. 57. Ed. F. J. W. Roughton and J. C. Kendrew, Butterworth, London. (1953). In Les Protéines, p. 63. Institut International de Chimie Solvay. Neuvième Conseil de Chimie. Stoops, Brussels, Itano, H. A., Singer, S. J., and Wells, I. C. (1949). Science, 110 543.

Perrier, C., and Jannelli, P. (1931). Arch. Fisiol., 29, 289.

Perut7, M. F. (1939). Nature, Lond., 143, 731. (1949). In Haemoglobin, p. 135. Ed. F. J. W. Roughton and

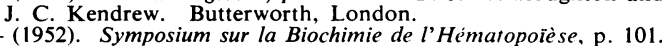
$2 e$ Congrès International de Biochimie, Paris.

(1953). Proc. roy. Soc. B., 141, 69.

Liquori, A. M., and Eirich, F.'(1951). Nature, Lond., 167, 929.

and Mitchison, J. M. (1950). Ibid. 166, 677

- and Weisz, O. (1947). Ibid., 160, 786.

Ponder, E., and Levine, P. (1949). Blood, 4, 1264

Porter, R. R., and Sanger, F. (1948). Biochem. J., 42, 287.

Porter, R. (1949). In Haemoglobin, p. 121. Ed. F. J. W. Roughton and J. C. Kendrew. Butterworth, London.

Powell, W. N., Rodarte, J. G., and Neel, J. V. (1950). Blood, 5, 887.

Prcsser, C. L. (1950). In Comparative Animal Physiology, p. 290 Ed. C. L. Prosser. Saunders, Philadelphia and London.

Putignano, T., and Fiore-Donati, L. (1948). Boll. Soc. ital. Biol. sper., 24, 277

Ramsay, W. N. M. (1949). In Haemoglobin, p. 231. Ed. F. J. W. Roughton and J. C. Kendrew. Butterworth, London.

Ranney, H. M., Larson, D. L., and McCormack, G. H. (1953). J. clin. Invest., 32.1277.

Rarer, A. B. (1949). E. Afr. med. J., 26, 281.

Reynaud, J. (1953). C. R. Soc. Biol., Paris, 147, 838.

Rich, A. (1952). Proc. nat. Acad. Sci., Wash., 38 187.

Riley, D. P., and Herbert, D. (1950). Biochim. biophys. Acta, 4, 374.
Roche, J. (1936). Essai sur la biochimie gin rale et comparée de pigments respiratoires. Masson, Paris.

— and Derrien, Y. (1953). Sang, 24, 97

Diacono, G., and Roques, M. (1953). Rev. Hemat., 8, 282

- - and Moutte, M. (1941). C. R. Soc. Biol., Paris, 135, 1235.

Rosenfeld, M., and Surgenor, D. M. (1950). J. hiol. Chem., 183, 663

Roughton, F. J. W. (1944). Harvey Lect., 39, 96.

- and Darling, R. C. (1944). Amer. J. Physiol., 141, 17.

Rubowitz, M. (1933). Biochem. Z. 266, 190

Sansone, G., and Cusmano, F. (1950). Boll. Soc. ital. Biol. sper., 26. 1343 .

Schenck, E. G. (1930). Arch. exp. Path. Pharmak., 150, 160

Schneider, R. G. (1953). Tex. Rep. Biol. Med., 11, 352 .

and Levin, W. C. (1950). Proc. Soc. exp. Biol., N.Y. 75, 110. chroeder, W. A., Kay, L. M., and Wells. I. C. (1950). J. bio!. Chem. 187, 221

Schulz, F. (1898). Hoppe-Sevl. Z. physiol. Chem., $24,449$.

Sherman, I. J. (1940). Bull. Johns Hopk. Hosp., $67,309$.

Silvestroni, E., and Bianco. I. (1952). Blood, 7, 429.

Singer, K., and Chernoff, A. I. (1952). Ibid., 7, 47.

- and Singer, L. (1951 a). Ibid, 6, 413 . — (1951b). Ibid., 6, 429.

and Fisher, B. (1952). Ibid., 7, 1216.

(1953a). J. Lab. clin. Med., 42, 193

(1953b). Blood, 8, 270.

and Singer, L. (1953). Ibid., 81008.

Slater, R. J., and Künkel, H. G. (1953). J. Lab. clin. Med., 41, 619.

Smith E. W. and Conley, C. L. (1953), Bull. Jo'ins Hopl. Hosp. 93, 94.

Sobotka, H. (1944). In Medical Physics, p. 763, Vol. 1. Ed. O. Glasser. Year Book Publishers, Chicago.

Spaet, T. H. (1953). J. Lab. clin. Med., 41, 161.

- Alway, R. H., and Ward, G. (1953). Pediatrics. 12, 483.

Stern, K. G., Reiner, M., and Silber, R. H. (1945). J. biol. Chem. 161, 73i.

Sturgeon, P., Itano, H. A., and Valentine, W. N. (1952). Blood, 7,350 .

Svedberg, T., and Nichols. J. B. (1927). J. Amer. chem. Soc., 49, 2920.

Svensson, H. (1948). Advanc. Protein Chem., 4, 251

Tiselius, A. (1937). Trans. Farad. Soc., 33. 524.

(1940). Harvey Lect., 19.10.39 in Buil. N.Y. Acad. Med., 16, 751 and Flodin, P. (1953). Advanc. Protein Chem., 8, 461.

Tristram, G. R. (1949a). Ibid., 5, 83.

(1949b). In Haemoglobin, p. 109. Ed. F. J. W. Roughton and J. C. Kendrew. London, Butterworth.

Trought, H. (1932). Arch. Dis. Childh., 7, 259.

Valentine, W. N., and Neel, J. V. (1944). Arch. intern. Med., 74. 185.

Valtis, D. J., and Kennedy, A. C. (1953). Glasg. med. J., 34, 521.

- D. (1954). Lancet, 1, 119,143

Vandepitte, J. M., and Louis, L. A. (1953). Ibid., ?. 806.

Vecchio, F. (1948). Progr. med., Napoli, 4. 201.

Vickery, H. B. (1944). J. biol. Chem. 156, 283.

Virtanen, A. I., and Laine, T. (1946). Nature, Lond., 157, 25.

Waris, E. (1954). Acta med. scand., 148, 167.

Watson, J. (1948). Amer. J. med. Sci., 215.419.

Wells, I. C., and Itano, H. A. (1951). J. biol. Chem. 188, 65.

White, J. C. (1954). In British Postgraduate Medical Federation' Lectures on the Scientific Basis of Medicine, Vol. 2, p. 287. 1952-53. Athlone Press, University of London.

Wieland, T. (1948). Angew. Chem., A, 60, 313.

Wootton, I. D. P. (1950). University of London, Ph.D. Thesis, Section 7.

Wyman, J. (1948). Advanc. Protein. Chem., $4,407$. - Rafferty, J. A., and Ingalls, E. N. (1944). J. biol. Chem., 153 275.

Wyman. J., Jr. (1949). In Haemoglobin, p. 95. Ed. F. J. W. Roughton and J. C. Kendrew. Butterworth, London.

Zinsser, H. H. (1952). Arch. Biochem. Biophys. 38, 195.

Zocher, H. (1925). Z $Z$. anorg. Chem., 147, 91 . 